\title{
La tipografía del cartel taurino en el siglo XIX
}

\author{
Begoña Torres GonzÁlez *
}

\section{RESUMEN}

En este artículo se aborda -por primera vez-el estudio de la tipografía en el cartel taurino del siglo XIX. Resulta una nueva aportación puesto que, sobre este

tema concreto, no existe ninguna bibliografía. Para llevarlo a cabo, se ha comenzado por intentar aclarar el panorama confuso de las clasificaciones tipográficas. Basándonos en la clasificación Vox -aceptada internacionalmente-se han diferenciado, uno por uno y de forma cronológica, el tipo de caracteres empleados en la cartelería taurina decimonónica.

También se han investigado los modelos estéticos, los intercambios entre imprentas, la perduración de diferentes estilos en el tiempo, el concepto tan peculiar de «legibilidad" del cartel, la relación con el libro y otros impresos, el diseño de letras manuales... en fin, la

estrategia de la comunicación, el atractivo de la representación y el inmovilismo, frente a la originalidad y la renovación.

\section{ABSTRACT}

This article addresses -for the first timethe study of graphic tipology represented in the bullfight affiche of the $19^{\text {th }}$ century. Since specific bibliography on the topic is inexistent, this is an innovative contribution to the field. The initial intention is to clarify the, so far, confusing classification of its graphic tipology. Following the internationally accepted Vox classification, the goal of the study has been to differenciate one by one, each typographic character in the tauromachy poster of the $19^{\text {th }}$ century. In addittion, this is an overview of the aesthetic patterns, the exchanges among printers, the persistency of certain styles throughout time, the alway peculiar concept of "legibility" in a poster, the relationships between a poster and other books and printed material, the design of the handwritten letters... and ultimately, the communication strategy, the appeal of representation and the dynamics between inmovilist attitudes and original and innovative ones.

* Museo Romántico. Madrid. 
Con el término tipografía designamos dos conceptos diferentes, aunque intimamente ligados. De un lado, el arte de juntar los caracteres para imprimir textos, formando palabras, líneas, párrafos, páginas ect; de otro, un procedimiento de impresión en el que la superficie impresora está constituida por elementos en relieve con relación a su soporte.

Estas dos técnicas han estado unidas desde el origen de la imprenta. En el periodo de tiempo en el que hemos analizado el cartel taurino, ambos aspectos también coinciden, ya que esta manifestación plástica se ha servido del sistema de impresión tipográfico para la comunicación de la palabra impresa. La tecnología aplicada al cartel taurino ha empleado la composición en caliente ${ }^{1} \mathrm{y}$ el procedimiento tradicional de impresión ${ }^{2}$. Habrá que esperar al último cuarto del siglo veinte para asistir a los nuevos conceptos introducidos por la fotocomposición, lo que se sale ostensiblemente de los límites de este estudio.

\section{LAS CLASIFICACIONES TIPOGRÁFICAS}

Los caracteres, en relación con el gusto de la época y con la evolución de las técnicas (procedimientos de impresión, tipo de papel, etc.), han adquirido proporciones diferentes (letras más o menos anchas o estrechas, finas o gruesas...) han modificado el "contraste" ${ }^{3}$ de sus anchos y sus estrechos, han inclinado o enderezado el eje de las letras redondas y han cambiado sus «remates» ${ }^{4}$. El conjunto de estas características sirve de punto de partida para la clasificación de los caracteres en familias, es decir, para su clasificación estilística.

i Composición en caliente: desde la puesta en servicio de las componedoras fotográficas, se ha dado este nombre a los procedimientos de composición que se utilizaban anteriormente y que que se distinguian porque reunían caracteres obtenidos por moldeo de metal en fusión. La composición, manual o mecánica, era el campo del relieve y el plomo. El offset y el huecograbado, industrializados en el primer cuarto de nuestro siglo, solo podían servirse de los textos de composición tipográfica. Recientemente la fotocomposición ha cambiado este estado de cosas. Dreyfus, J.y Richaudeau, F. Diccionario de la Edición y de las Artes Gráficas. Madrid, Biblioteca del Libro Germán Sánchez Ruipérez, Ediciones Pirámide S.A.,1990, págs.114-120.

2 Hasta el primer cuarto del siglo $x x$-fecha en la que comienza a introducirse la composición mecánica- la composición tipográfica de los carteles era manual.

3 Contraste: diversidad en la densidad de trazo de los caracteres.

4 Remate/Terminal: forma dada a la cabeza y a la base de las partes verticales y oblicuas de las letras impresas. Son de forma y espesor diferente según el estilo de las letras a que pertenecen. 
Como consecuencia de la variedad de caracteres de impresión que impedía un completo entendimiento del vocabulario tipográfico, se han propuesto diferentes sistemas de clasificación, obra de otros tantos tratadistas: François Thibaudeau, Maximilien Vox, Heinrich Siegert, Aldo Novarese, etc.

La clasificación Vox, fue aceptada por la Asociación Tipográfica Internacional (A TYP I) que oficializó en Verona, en 1962, las nueve familias pertenecientes a la misma, a las que añadió dos más. La clasificación que lleva el nombre de Maximilian Vox había sido puesta a punto en 19531954 por la "Retraité graphique internationale de Haute Provence» en Lurs. Se basa en la realizada por Thibaudeau ${ }^{5}$ en 1921 pero, mientras que ésta no consideraba más que las formas y remates, la primera, más completa, tiene en cuenta la historia y el estilo.

Muchos de los nombres dados antes a las grandes familias de caracteres, cambian su significación dependiendo de los países; así la que en Francia se llama «Antique» es la "Gothic» en Inglaterra, mientras que para los alemanes Antique (antigua) significa romana. La clasificación Vox-A TYP I introdujo una serie de tipos que acabaron con la confusión reinante, permitiendo una traducción casi siempre identificable de una lengua a otra.

Para el estudio de la tipografía en el cartel taurino es imprescindible partir de una clasificación uniformada de los caracteres de composición. Hemos aceptado para este análisis el uso de la Vox-A TYP I que se basa en once familias: las Clásicas: Humanas, Garaldas y Reales; las Modernas: Didonas, Mecanas y Lineales, además de las Incisas, Escriptas y Manuales; a esta primera clasificación se le añadió, posteriormente, las Fracturas (que habian sido clasificadas por Vox entre las manuales) y las formas no latinas A continuación, llevaremos a cabo una breve descripción de las diferentes familias que integran esta clasificación, ya que, a lo largo de este escrito, será continua la referencia a las mismas ${ }^{6}$.

5 Thibaudeau propone una clasificación en cuatro familias básicas: «Romano Antiguo» (Ezelviro) que se distingue por la desigualdad de espesor en el asta y por la forma triangular y cóncava del remate; "Romano Moderno» (Didot) de asta muy contrastada con el terminal que es siempre fino y recto; «Egipcio» de asta uniforme y remate rectangular y «Palo seco» (Antiguo) de asta uniforme y sin remates.

6 Dreyfus Y Richaudeau. Op.cit.

Mclean, Ruari. Manual de tipografia. Madrid, Herman Blume, 1987, págs.58-78. 


\section{Clásicas}

\section{Humanas ${ }^{7}$}

Proceden de los tipos llamados Venecianos, creados a finales del siglo xv por Nicolaus Jenson y otros grandes impresores. Se inspiraron en la escritura humanística de los eruditos, que había retomado la carolingia de Carlo Magno, antecedente de nuestra minúscula (caja baja).

Las humanas tienen un trazo firme y un aire artesanal. Sólidamente asentadas en sus remates amplios llevan generalmente una "a» sin lágrima, el asta oblicua de la «z» en fino y la "e» cruzada oblicuamente; sus versales alinean con los palos de la caja baja «largos por arriba».

Históricamente las garaldas reemplazaron a las humanas, de las que no se vuelve a hablar antes de la renovación tipográfica de finales del siglo XIX, comenzada por el "golden type" de William Morris y seguida por ciertas creaciones de Grasset, Goudy, Zapf, así como por Bruce Rogers con la «Centauro».

\section{Garaldas}

Su nombre es un homenaje a los dos creadores de los caracteres del Renacimiento italiano y francés (Garamond y Aldo Manuzio). Se clasifican bajo este título las redondas que, desde finales del siglo $x \mathrm{~V}$ hasta la segunda mitad del XVIII, eran de uso corriente en toda Europa. Son menos rústicas que las humanas y más elegantes por el aumento de contraste entre gruesos y finos, el refinamiento de los remates, y la reducción de la altura de sus versales.

\section{Reales}

El prototipo es el romano del rey de Grandjean (1694) seguido, sesenta años más tarde, solamente de Baskerville. Su ojo es más estrecho que los anteriores, sus gruesos están distribuidos según un eje vertical, sus remates son más discretos.

7 Dreyfus y Richaudeau. Op.cit., pág. 259. 


\section{Las Modernas}

\section{Didona}

Es un homenaje a las obras de Didot y Bodoni. Las mejoras aportadas a la prensa tipográfica y la aparición de papel vitela, permitieron las oposiciones violentas (características del estilo) entre gruesos muy negros y finos exageradamente filiformes. Otras características son la verticalidad del eje de las letras redondas, la rigidez de las letras rectas y la delgadez de los finos.

La propaganda y la publicidad se ha nutrido de ellas en el pasado y también en la actualidad, gracias a la versatilidad de su diseño que se presta a todos los caprichos de la imaginación: anchos, estrechos, finos, negritas etc.

\section{Mecana}

En la clasificación Thibaudeau es la «egipcia», de asta uniforme y remate rectangular, casi siempre del mismo grueso que ella. Procede de una época de auge industrial y maquinismo y de ahí deriva su nombre. La mecana se presta a la abundancia del adorno romántico: alfabetos orlados, calados, perlados, abiertos, sombreados, grises, ilustrados. Es el carácter mecanográfico por excelencia. Las mecanas más corrientes son las «menphis», «béton», «clarendon», «rockwell», «volta», «egizio», «melior», «serifa», «dattilo».

\section{Lineales $^{8}$}

Agrupa el conjunto de caracteres desprovistos de remate. Corresponde a las «antiguas» o "palos» de la clasificación Thibaudeau. Se llaman "Sans Serif» en el Reino Unido, "Gothics» en Estados Unidos y "Grotesk" en Alemania. No fueron introducidas en tipografía hasta comienzos del siglo XIX — con el nombre de English Egyptian (William Caslon IV, Londres 1816) - únicamente en forma de versales. Las primeras letras de caja baja vinieron más tarde (Figgins, 1832).

8 Dreyfus y Richaudeau. Op.cit., pág. 527. Ponot, L. "Les lineales", Le Courrier Graphique». N. ${ }^{\circ} 109,1960$. 
Su trazado, muy esquemático, constituía un comodín para los escritores litógrafos, quienes las diseñaban para los textos utilitarios, preferentemente en caracteres filiformes $y$ en cuerpos pequeños.

Entre 1816 y 1920 la lineal de imprenta servía, casi exclusivamente, para la composición de carteles y anuncios publicitarios. El libro no la utilizaba salvo en casos aislados, como en alguna portada o cubierta, durante la época romántica.

A pesar de los logrados ensayos para el metro londinense en 1916, habrá que esperar a la influencia de la Bauhaus para que se imponga una segunda ola de lineales: "la futura» (llamada "europe» en Francia por Deberny y Peignot) supone el triunfo del funcionalismo y del tiralíneas y el compás, siendo la más célebre y difundida de los tipos de su género.

\section{Incisas $^{9}$}

Su prototipo es la capital romana de inscripción (siglo I) utilizada, durante el Renacimiento, por Durero, Tory, etc.

A finales del siglo pasado, las «latinas» pretenden adaptar a su época el estilo de las inscripciones de la columna de Trajano. Provistas de remates triangulares llevados hasta lo agudo, son monótonas, de elegancia artificiosa. El escultor-grabador Eric Gill, realiza la "perpetua», que es una incisa-garalda, lo que lleva a constatar que la incisa se adapta mal a la escritura continua, sólo una fuerte herencia garalda puede hacerla verdaderamente tipográfica.

\section{Escriptas ${ }^{10}$}

Imitan la escritura corriente. Excluida de las escriptas la cursiva, la primera versión tipográfica de una escritura fue, en 1557, la letra «civilité» de Robert Grajon.

Cerca de un siglo más tarde, Pierre Moreau, maestro calígrafo que se había hecho impresor, graba los punzones de una bastarda (1643). Fournier el Joven (1760), Guillé padre (1780) e hijo (1802), Bodoni (1808) graban escriptas. Vienen luego las Didot y sus inglesas y, posteriormente, la litografía.

La proliferación de trabajos de remendería da lugar a la aparición de una multitud de escrituras litográficas. Por reacción, la tipografía multiplica

\footnotetext{
Dreyfus y Richaudeau. Op.cit., págs. 434-5.

IBIDEM, pág. 191
} 
las redondas, bastardas e inglesas de todas las inclinaciones y de todos los gruesos, bautizadas litográficas, autográficas, tallas dulces, verticales, francesas, parisinas, caligráficas. Hasta el siglo xx, las escrituras han permanecido estrictamente caligráficas ${ }^{11}$; con el desarrollo de la publicidad se convierten en personalizadas ${ }^{12}$.

\section{Manuales}

Agrupan los tipos en que predomina la influencia de la mano. Caracterizadas por el ritmo lento de una escritura a mano posada, son caracteres personalizados, influidos por el trabajo del cepillo, el pincel o la pluma ancha. Concebidos fuera de toda idea de lectura continua, escapan a todas las exigencias estilísticas de rigor para los caracteres de texto. Generalmente quedan reservadas para trabajos de remendería, de fantasía, de lujo o publicitarios.

La diferencia es a veces mínima entre una manual y una escripta, puesto que en el origen la escripta es una manual cursiva a mano alzada ${ }^{13}$.

\section{Fractura}

Es uno de los estilos alemanes de la escritura gótica. Los caracteres góticos fueron decayendo en la escritura y en la imprenta desde finales del siglo $\mathrm{XV}$ en adelante ya que, en el Renacimiento, se fue introduciendo, paulatinamente, el tipo romano que se llamó «humanístico». A finales del siglo XIX asistimos a un resurgimiento de la tipografía gótica.

\section{Otras clasificaciones:}

Hasta el momento hemos expuesto brevemente la clasificación de los caracteres siguiendo criterios morfológicos, en grupos estilísticos ${ }^{14}$, familias ${ }^{15} \mathrm{y}$ series ${ }^{16}$.

\footnotetext{
11 Las escriptas caligráficas actuales son casi exclusivamente inglesas.

12 Escriptas personalizadas: grafías inéditas diseñadas, como las manuales, con pincel, cepillo, difumino, bolígrafo... y realizadas normalmente por fotocomposición.

13 La diferencia entre una escripta y una manual es que, la primera, es una escritura realizada a mano corrida mientras que, la segunda, lo es a mano posada.

14 Estilo: es la forma o características peculiares de un alfabeto o grupo de caracteres.

15 Familia: es el conjunto de caracteres de los distintos cuerpos y series que son del mismo estilo.

16 Serie: es cada una de las variedades dentro de una familia: redonda, cursiva, negra, estrecha, ancha...
} 
Desde los primeros ejemplos podemos descubrir en el cartel taurino una evolución tipográfica por familias o estilos, coincidiendo con el natural desarrollo de la misma en el ámbito del impreso en general. Por esta razón, nos ha parecido oportuno alargarnos más de la cuenta en el estudio de esta clasificación estilística en la que las distinciones se llevan a cabo a través de la forma diferente de los elementos que constituyen la letra: el asta (elemento necesario) y el remate o terminal (elemento casi exclusivamente decorativo).

Pero además de esta clasificación, centrada casi exclusivamente en el estilo y las familias, existen otras formas de clasificar los caracteres basadas en las series y en el uso al que se destinan dentro del impreso y que, aunque son conocidas por todos, expondremos brevemente.

La cartelería taurina, a diferencia del cartel comercial publicitario, exige un largo texto explicativo, que en los primeros momentos (desde el siglo XVIII hasta el último cuarto del XIX) dominará claramente sobre la ilustración. El cartel de toros emplea multitud de caracteres que se mezclan de manera indiscriminada en el mismo y que podemos clasificar en cuatro grandes grupos: caracteres comunes o de texto, titulares, caracteres de escritura y de fantasía.

Los caracteres comunes son los que se utilizan en la composición del texto y suelen ser de la serie denominada «redondo» que es la normal, de trazo vertical y más bien fina. Forman parte de los caracteres comunes además del redondo, las series de la cursiva, las versalitas y las negritas.

"Cursiva o Italica" es la letra de igual tamaño y familia que el redondo correspondiente, diferenciandose de este por su inclinación y por cierta semejanza con la escritura a mano. Lo normal es emplearla unicamente en medio del texto compuesto de tipo redondo, para destacar palabras a las que se quiera dar más importancia. La cursiva, por su inclinación, destaca suficientemente en medio del redondo y, como tiene el mismo grueso de asta que él, no rompe la armonía.

Las «Versalitas» son letras sólo mayúsculas, de igual altura de ojo que las letras minúsculas del mismo cuerpo, que no tienen asta ascendente ni descendente. Se usan para las frases o palabras que deban diferenciarse de la cursiva y del redondo, y suplen, muchas veces ventajosamente, a las negritas, destacando suficientemente y sin romper la armonía del texto, por su trazo de igual grueso que el del redondo y la cursiva.

Las «Negritas» son las letras mayúsculas y minúsculas del mismo tamaño y forma, pero de trazo más grueso que el redondo del mismo cuerpo 
y familia. Suelen fundirse con el trazo vertical o redondo, a veces, de cursiva. Las negritas se usan para el encabezamiento o cuando se quiere destacar alguna palabra en medio del texto (tal es el caso de los nombres de los lidiadores).

Las «Titulares» se utilizan para las palabras del encabezamiento ya sean sólo letras mayúsculas o mayúsculas y minúsculas.

Los "caracteres de escritura» son los que imitan, de algún modo, cualquier letra manuscrita. En la clasificación Vox corresponden a los que hemos denominado escriptas.

Los «caracteres de fantasía» o «historiados» son los que están adornados con rasgos, figuras, símbolos, etc. Por sus formas variadas se diferencian de los caracteres comunes, utilizándose para la composición de trabajos comerciales, títulos, impresos publicitarios, etc. Son muy abundantes en el cartel taurino, sobre todo durante el siglo XVIII y primera mitad del XIX, y se emplean únicamente para el encabezamiento recibiendo, según su forma, diferentes nombres: sombreados, fileteados, lapidarios ... La tradición de decorar los caracteres tiene mucho que ver con el uso de las «iniciales decoradas» u "ornadas» ${ }^{17}$ que perviven en la imprenta como admiración de los miniados manuscritos medievales.

Las iniciales ornadas ${ }^{18}$ son clasificadas por Jennings ${ }^{19}$ en cuatro tipos: las «antropomórficas", en las que los ornatos se confunden formando la inicial misma, que resulta alterada en su forma originaria. El segundo tipo es de simples ornatos, más o menos espesos o arabescados, que circundan la inicial sin alterarla. En el tercero, la inicial mayúscula se superpone a una figura o escena, comúnmente inspirada en el argumento del libro. El cuarto tipo son las simples o complicadas rúbricas caligráficas.

La más usual ha sido la «inicial arabescada» o "florida», que tiene su principal desarrollo durante el Quattrocento. Las formas de los arabescos fueron de tres tipos, según Johnson ${ }^{20}$ : de simples tallos vegetales, con múltiples volutas de flores fantásticas u hojas y flores más naturales, sien-

\footnotetext{
17 Sobre este tema vid. SMrth, P. «/nitial letters in the printed book», The Fleuron, N. ${ }^{\circ}$ 1, Ed. du Chene, 1923. págs. 61-91.

18 BORGES, Juan. "Arquitectura del libro de arquitectura (1511-1842). Refugios de la utopía», Fragmentos. Núms. 17,18 y 19. Madrid, 1991, págs.93-109.

19 Jennings, J. Early woodcut initials. London, 1908.

20 Johnson, A.F. Type Desing, Their History and Development, London, The Clarendon Press, 1959.
} 
do habitual también el uso de nudos más o menos complicados formando arabescos desarrollados, gran parte de las veces con la estructura llamada del «lirio del valle».

Por supuesto este tipo de iniciales, talladas primero en madera mediante tacos rectangulares y posteriormente calcográficas, no se utilizan en el cartel taurino; sin embargo sí se emplean, fundamentalmente en el siglo xVIII y hasta el 1840, mayúsculas tipográficas muy decoradas siguiendo el esquema del segundo tipo de iniciales ornadas, es decir aquellas decoradas con vegetales flores 0 arabescos y, dentro de esta categoría, aquellas tipologías con tallos vegetales y volutas.

Pero la conexión entre el cartel de toros y el libro no se encuentra únicamente en la utilización de este tipo de caracteres de fantasía, sino que la configuración general del cartel de toros, en los primeros momentos, sigue también atentamente la idiosincracia y disposición del libro impreso.

El cartel de toros no solamente utilizará los mismos caracteres -en cuerpos mayores- que los empleados en el libro - puesto que, en un principio, no se funden caracteres específicos para el cartel- sino que también recibirá la influencia de éste en la forma de disponer la tipografía. A pesar de que los primeros ejemplos del siglo XVIII - y hasta el año 1840 más o menos - tienen un formato horizontal -a diferencia de las portadas de los libros que se desarrollan en sentido vertical- la disposición de la tipografía, la distribución de los blancos, el uso de diferentes caracteres (redondos, cursivos, versales, caja baja...) la utilización de bigotes, el enmarcado por medio de orla... recuerda - salvando lógicamente las distancias entre un impreso popular y otro más elaborado- las portadas tipográficas irregulares del libro impreso.

\section{EVOLUCIÓN DE LA TIPOGRAFÍA EN EL CARTEL TAURINO}

Nuestro primer interés se ha centrado en el análisis de la evolución de los estilos y familias tipográficas en el cartel taurino. Esta meta ha supuesto multitud de inconvenientes por varias razones: en primer lugar, por tratarse de un tipo de impreso eminentemente popular, que no ha sido construido, desde el punto de vista tipográfico, con un diseño unitario, ni con una preocupación estética o de originalidad. Este hecho ha propiciado la utilización indiscriminada, dentro del mismo impreso, de diferentes familias y estilos tipográficos, recurriendo siempre para la composición a aquellos caracteres que se tenían más a mano, sin una idea preconcebida 
de construcción racional y lógica. En segundo lugar porque tampoco se ha dotado a la cartelería taurina de una tipografía moderna acorde con la evolución de los nuevos tiempos, por lo que podemos apreciar continuas pervivencias y contaminaciones de estilos antiguos que se mezclan sin ningún prejuicio con los más nuevos.

Pero a pesar del carácter popular y secundario del cartel taurino, que dispone los diversos elementos del impreso - masas de texto, ornamentación, títulos, márgenes...- en una composición compleja (llamada comunmente de «remendería» o composición de remiendos), hemos intentado clarificar y distinguir la evolución e idiosincracia de su tipografía, por lo que creemos puede aportar nuevos datos al estudio general sobre el tema.

\section{La tipografía del cartel taurino en el el siglo XVIII}

Los primeros carteles taurinos estaban armados solamente con elementos tipográficos, teniendo como única decoración una orla o simple filete delimitador. Por lo que respecta a los caracteres empleados, se utilizan básicamente los tipos romanos clásicos, denominados hasta hace bien poco en España «Elzevirianos» (de Elzevir). Algunas características autóctonas, como los famosos "gilismos» que Geronimo Antonio Gil introdujo en los tipos grabados para la Imprenta Real de Madrid, caracterizados por sus famosos espolones o aristas, pueden verse también en muchos de estos primeros impresos.

En el siglo XVIII se utilizan versales y caja baja; en algunas ocasiones, se introducen versalitas en líneas determinadas. Las versales normalmente se emplean para resaltar aquellas frases de mayor importancia en el texto, haciendo las funciones de titulares o capitales: encabezamiento con el nombre del rey, el lugar, la fecha, el número de corrida y el propio anuncio de la corrida de toros, la presidencia y aquellas frases o palabras que se quieren subrayar de alguna manera por su importancia: picadores, lidiadores, aviso al público, hora de festejo, etc. El resto del texto suele ir en caja baja, con caracteres normales de obra, generalmente redonda, aunque también se utiliza la cursiva (por ejemplo para los motes de los matadores).

Desde finales del siglo xvIII el encabezamiento o título del cartel aparece en versales de tipo romano muy ornamentadas: mayúsculas perladas, floreadas, con decoración de elementos arquitectónicos clásicos como los balaustres, las hojas de acanto, u otros temas vegetales, iniciales 
sombreadas, decoradas, con formas en relieve a base del juego de las líneas blancas y negras etc.

\section{La Tipografía del cartel taurino en el siglo XIX}

De 1800 a 1880

El breve análisis que ahora avanzamos sobre la tipografía del cartel taurino se centra fundamentalmente en el siglo XIX, que supone quizá el momento de mayor creación de tipos de la historia, aunque verdaderamente falto de calidad desde un punto de vista estrictamente tipográfico.

Los primeros ejemplos de cartelería taurina en el siglo XIX emplean la familia tipográfica que Thibaudeau denominó como "romano moderno" ("Didona» en la clasificación Vox), creándose las tipologías «finas», "negras» y "supernegras» en cuanto al grueso del palo, así como las "estrechas» $y$ «anchas» por lo que respecta al ojo.

Los carteles tienen todavía un formato horizontal, dividido generalmente en dos mitades por medio de un filete; en la mitad superior, se utilizan mayúsculas de diferentes cuerpos así como cursiva, la mitad inferior, está compuesta en caja baja en caracteres de obra cursiva y redondo.

Los carteles de 1833 componen el encabezamiento en romano moderno muy simplificado; utilizan caracteres muy decorados: letra orlada abierta en gris; de tipología parecida a la «Mecana», con remates rectangulares y asta uniforme. Para el resto del texto emplean caracteres de fantasía abiertos en blanco y decorados; caracteres en negrita de la familia "Didona» y caja baja en redonda y cursiva.

La letra orlada ${ }^{21}$ es la característica de la época romántica. Son caracteres de época donde la anécdota, el rasgo de pluma, el dibujo sentimental predominan claramente. La letra romántica del cartel taurino no suele tener formas tan caprichosas y anecdóticas como las utilizadas para el libro y, aunque muy decorada, es más austera y publicitaria. Sin embargo el centro

21 Letra orlada: letra inicial, casi siempre mayúscula, provista de un adorno. El adorno (lazos, animales, flora, elementos geométricos...) se aloja en el grueso mismo del cuerpo de la letra (palos, vientre, barras) o fuera y al exterior de ella (en este caso se trata de letras titulares orladas). También se las puede denominar, según el aspecto formal de las letras, letras abiertas o blancas, porque la luz las atraviesa y letras grises, cuando su luz queda cortada por trazos finos. Tienen su origen en las iniciales de los manuscritos. P.S. Fournier fue el primero que se afanó en reproducir en punzones letras orladas para convertirlas en caracteres tipográficos. 
de referencia para los carteles sigue siendo el libro: no se realizan tipografías específicas para estos impresos publicitarios, ya que los cuerpos grandes son simplemente caracteres de obra aumentados.

Era costumbre, durante el siglo XIX, que los cajistas efectuaran una serie de ejercicios tipográficos que consistían en modificar los caracteres mediante lima y cuchillo, creando así nuevas formas tipográficas que se distinguían de las seriadas de fundición. Son lo que podemos denominar como caracteres de fantasía, muy decorados, fracturados con remates hendidos o bifurcados.

Este tipo de caracteres se emplearon profusamente en el cartel isabelino (Fig. 1), que tiene ya unas características muy configuradas: greca delimitadora con mayor protagonismo y decoración, con hojas de acanto de raiz neoclásica; encabezamiento con tipografía en versal de importante tamaño (unos 60 puntos) con caracteres romanos muy decorados y elementos vegetales también basados en la hoja de acanto, dispuestos creando un verdadero «trompe-l'oeil» en relieve. Este tipo de caracteres de fantasía, se reserva para las frases claves del cartel: "LA REINA»/

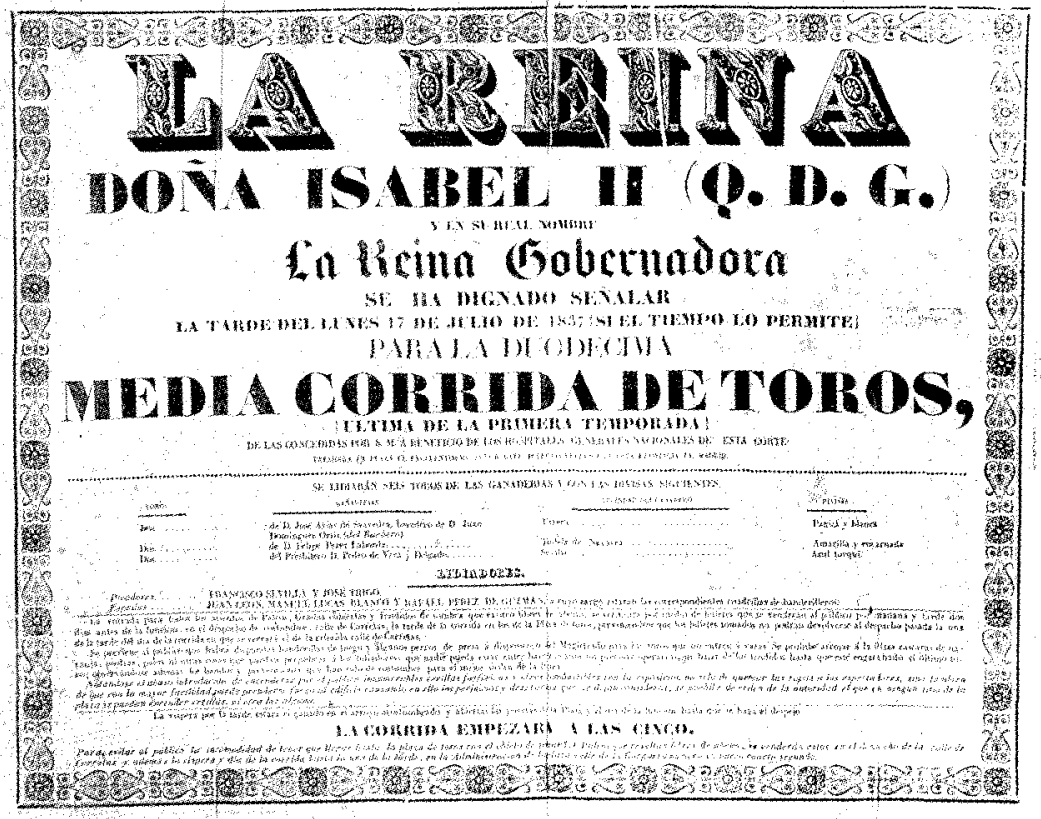

Fig. 1. Cartel isabelino, 1837. M.N.A. 
(capitales decoradas con vegetales y ovas) «DOÑA ISABEL II Q.D.G./ (negrita de la familia Didona) y más abajo «La Reina Gobernadora» (letra gótica Ilamada en la clasificación Vox Fractura). La vuelta a la Edad Media trae consigo un retorno de la letra Gótica, no tanto como escritura de texto, sino como pretexto decorativo. El resto de la información, separada por un filete, va en caracteres de obra normales.

En el campo de la letra, donde predomina la Didot, se establece una diferencia más neta que nunca entre los caracteres para leer y los caracteres para ver: los de los textos y los de los títulos. Ya entorno al 1800, Robert Thorne diseñó en Inglaterra un alfabeto neoclásico en negrita - cuyos gruesos eran exageradamente anchos-y que se populariza inmediatamente (primeras versiones de negritas anchas y negras 0 supernegras). La negrita fue una verdadera revolución, algo nuevo, un caracter hecho para «tirar» del receptor, por lo que se empleó principalmente en los impresos publicitarios.

En estos momentos, en el cartel taurino las frases más importantes se realizan en caracteres latinos versales en negrita de la familia Didona, con las clásicas oposiciones violentas entre gruesos muy negros y finos exageradamente filiformes. Podemos considerarlo quizá como el primer estilo utilizado para la propaganda y la publicidad. A principios del siglo XIX, es moda recargar los «Didot» y una de las versiones de estos Didot extranegros, ni ensanchada ni alargada, conservando la finura de sus perfiles del tipo puro, pero apartándose de ella por el pronunciado engrosamiento de las astas, conoce un éxito duradero con el nombre de «normanda» que es un tipo muy utilizado en la cartelelería taurina entorno a los años de 1840 (Fig. 2).

También hacia 1840 el cartel de toros comienza a desarrollarse en vertical, utilizando en el encabezamiento una letra normanda (Didot recargado) extranegra y chupada, de remates muy geométricos (Fig. 3). Es curioso comprobar como en la tipografía del encabezamiento se emplean dos clases diferentes de familias para una única frase: «PLAZA»/ (Didot recargado) «DE»/ (Mecana de remates rectangulares) «TOROS» (Didot recargado). Separado por un bigote, el resto del texto en caja baja, combina una tipología clásica con caracteres bastardos de forma próxima a la redonda inclinada y caracteres inclinados en cursiva.

No podemos olvidar la importante tradición caligráfica española, ni la creación en 1550 de la bastarda española por Juan Yciar ${ }^{22}$, que todavía

22. García Morales J. "Orthografía práctica de Juan de Yciar» en Colección Primeras Ediciones, Madrid, Instituto Bibliográfico Hispánico, 1973. 


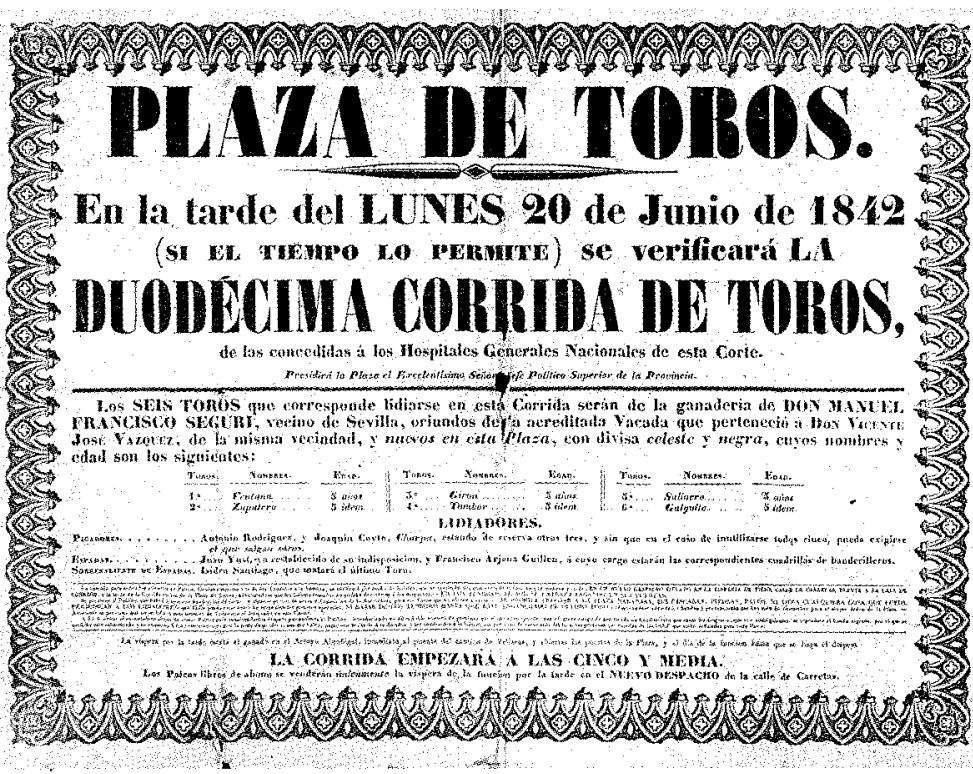

Fig. 2. Cartel fechado en 1842. M.N.A.

hoy sigue en vigor. Según Satue ${ }^{23}:$ «...tan larga y acreditada tradición supuso que los métodos caligráficos tuvieran especial incidencia en la educación general a partir de 1835, en que se usa en las escuelas el «Arte de escribir letra bastarda española” del célebre José Francisco de Iturzaeta, en una carrera tipológica de la que probablemente emana la obra impresa de rotulistas de nuestro siglo...".

En estos momentos quedan fijadas definitivamente una serie de características que se mantendrán en la mayoría de los carteles del siglo XIX (Fig. 3). Además del formato en vertical y el encabezamiento iniciado con la fórmula: «PLAZA DE TOROS», desde el punto de vista tipográfico, se introducen también algunas novedades: el aumento del tamaño en el cuerpo de las letras utilizadas en el encabezamiento, el uso sistemático de versales negritas (en el encabezamiento y, más abajo, en el anuncio del tipo de espectáculo: «LA VIGÉSIMA MEDIA CORRIDA DE TOROS»); la utilización de cursiva para la fórmula «si el tiempo lo permite» ${ }^{24}$ —que

23 Satue, Enric. El diseño gráfico desde los origenes hasta nuestros días. Barcelona, Alianza Editorial, 1990, pág. 438.

24 Con anterioridad esta fórmula siempre se escribía en versales. 


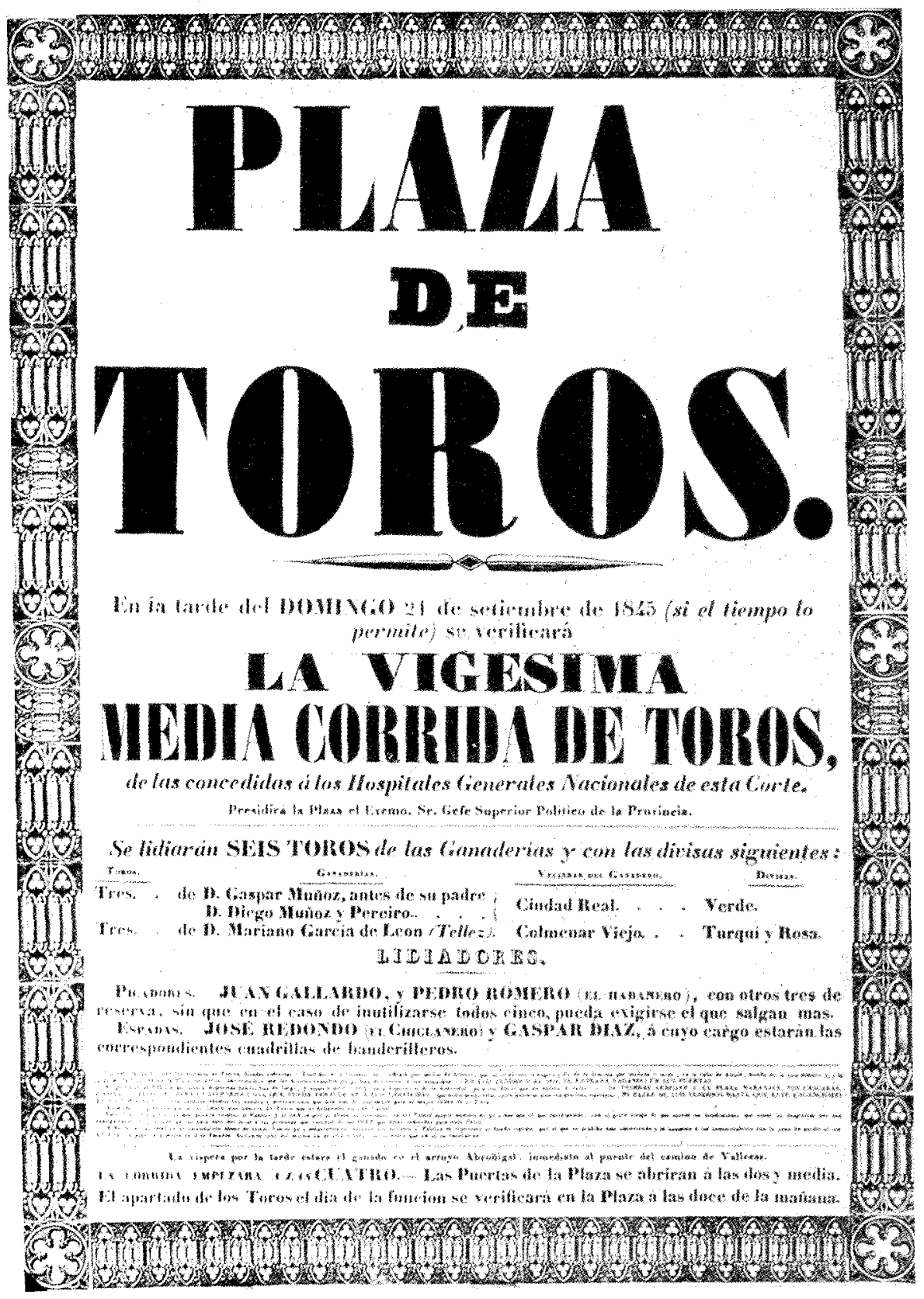

Fig. 3. Cartel fechado en 1845. M.N.A. 
siempre va entre paréntesis- y el uso de versalitas y caja baja, redonda y cursiva para el resto del texto.

Sin embargo será a partir de los años 1845-1850 cuando aparezca en el cartel taurino la primera renovación de los caracteres tipográficos, con el empleo sistemático de la familia tipográfica de la "egipcia" que se corresponde con la «Mecana» en la clasificación Vox.

La mecana era un carácter con todos los trazos de igual grosor, incluidos los remates. Fue utilizada fundamentalmente para titulares, de ahí su aplicación a los impresos publicitarios cada vez más abundantes en el siglo xIx. En torno al 1848, aparece también en Inglaterra lo que se ha denominado como "estilo Clarendon»: se trata de una egipcia o mecana negra, ligeramente estrecha, de remates redondeados, con versales y caja baja.

Esta familia de caracteres se mantendrá en el cartel taurino prácticamente hasta nuestros días (Fig. 4). Las mecanas desarrollaron diferentes evoluciones, desde las versiones de Thorne, hasta las posteriores creaciones sombreadas, estrechas ${ }^{25}$, perfiladas, a las que se llamó genéricamente «jónicas», para desembocar en una bella síntesis aparecida en Inglaterra en 1860.

Pero la gran revolución de la tipografía moderna y publicitaria fueron los caracteres llamados de "palo seco» (Lineales en la clasificación Vox). En opinión de Jock Kinneir ${ }^{26}$ el origen de los tipos de palo y de las mecanas está en los pintores de rótulos comerciales ${ }^{27}$. Los contrastes entre los palos finos y gruesos de la tipografía anterior, suponían una verdadera dificultad para el pintor que realizaba los rótulos manualmente, por lo que llegó a forzar un trazo más grueso en toda la letra; de otro lado, la visibilidad de los grandes anuncios, suponía también una buena razón para adoptar esta tipología.

Las tipografías lineales o de "palo seco» (llamadas también antiguas, grotescas y góticas) fueron diseñadas por el ingles William Caslon IV en 1816. Los rasgos de esta familia pueden variar de espesor pero normalmente tienen los palos finos del mismo calibre que los gruesos y carecen totalmente de remate.

25 La letra estrecha o chupada, creada y usada fundamentalmente para componer libros de poesía, se llamó en sus orígenes (siglo XIX) letra «poética». Con el recurso de estrechar el tipo se resolvía, en gran parte, el problema compositivo que planteaban los versos cuya longitud excedía a menudo la caja tipográfica y obligaba a doblar línea con demasiada frecuencia, con lo que la forma original del poema se veía seriamente desvirtuada. (SATUE, Op.cit., pág. 87, nota: 6).

26 KINNEIR, J. El diseño gráfico en la arquitectura. Barcelona, Gustavo Gili, 1982.

27 Sobre rótulos comerciales vid. ALEGRE PALAZÓN, M. «La tienda, su cartel y sus letras» en Establecimientos Tradicionales Madrileños, Madrid, Cámara de Comercio e Industria, Vol. 1, 1980. 


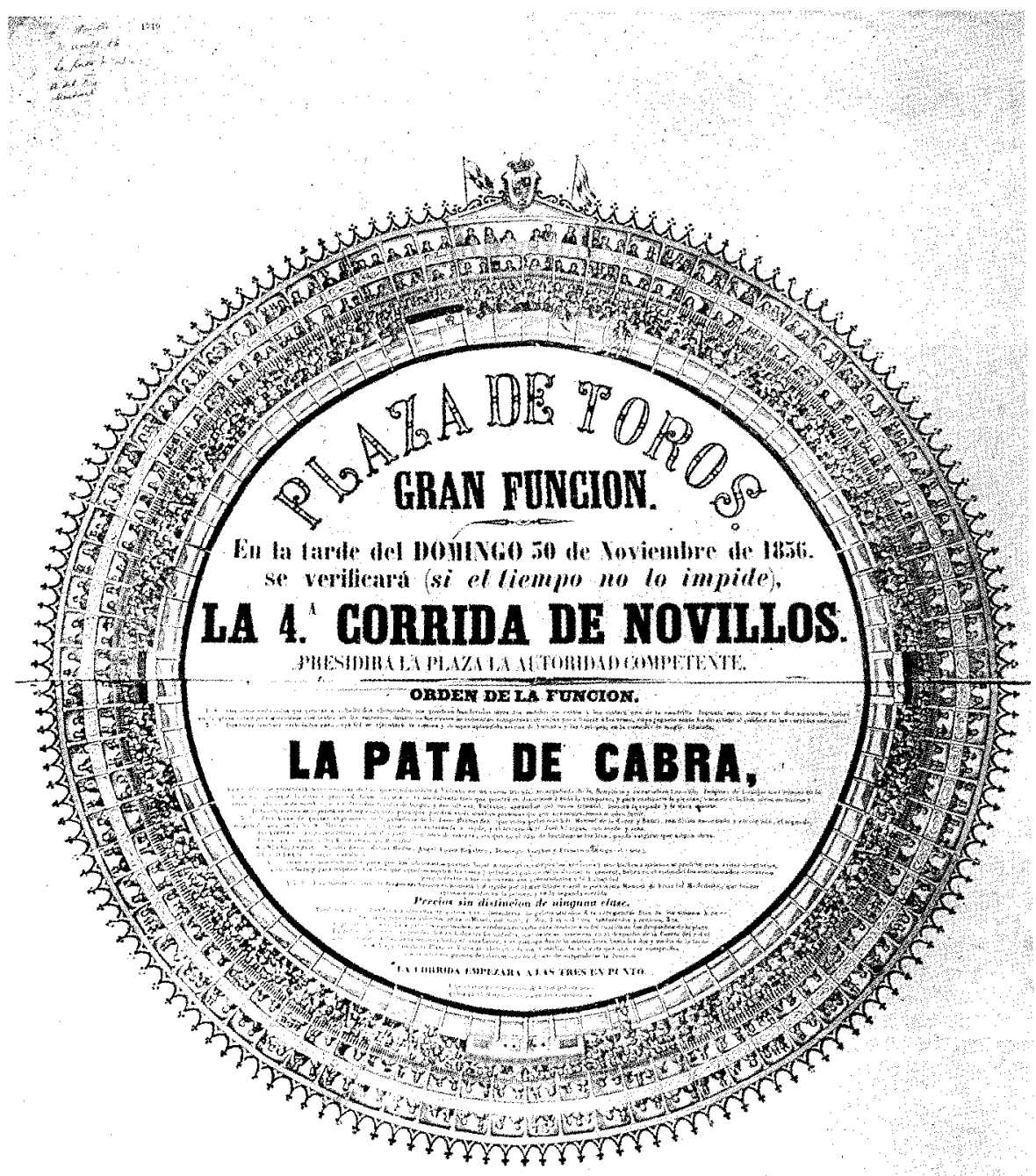

Fig. 4. Carte! fechado en 1850. M.N.A.

Los primeros ejemplos de esta familia en el cartel taurino se remontan a 1850 más o menos (Fig. 5). Los grandes carteles de desarrollo vertical, en los que aparecen las primeras maderas de calidad, tienen el encabezamiento con el título: «PLAZA DE TOROS», en versal, grande, negrita, 


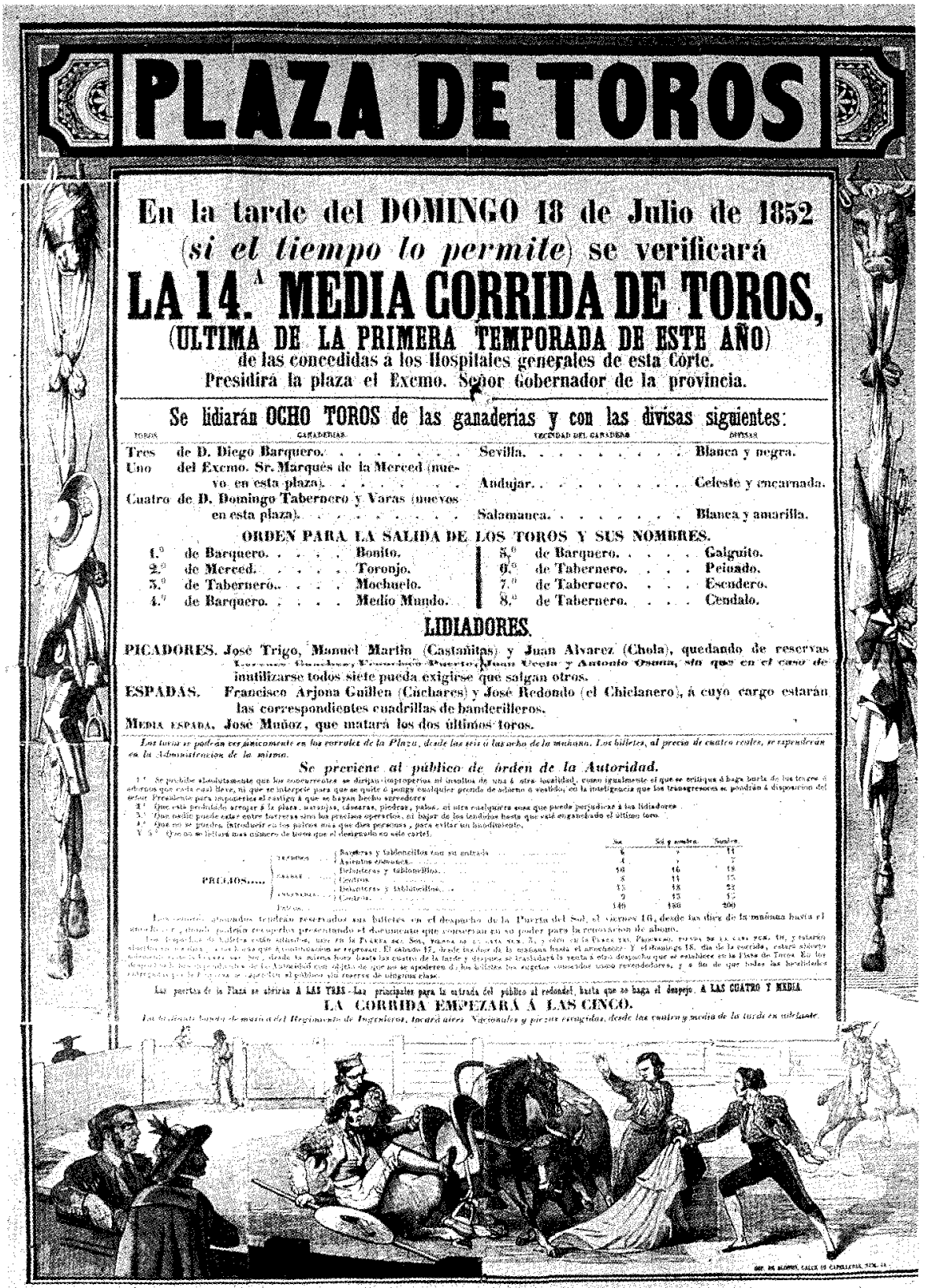

Fig. 5. Cartel fechado en 1852. M.N.A. 
con efecto de relieve y de la familia lineal. En estos primeros ejemplos la tipografía no se ha configurado todavía, por lo que los gruesos y finos no son idénticos.

Como hemos visto, desde el año 1837, comienzan a aparecer, aunque esporádicamente, tipografías de tipo gótico - Fracturadas en la clasificación Vox- haciendo alusión a la ruptura de los principales trazos curvos de la letra y sus terminales hasta formar ángulos. En esta primera aparición, se trata de la llamada "gótica de forma» 28: son caracteres comprimidos y angulosos; los de caja baja, no llevan curvas y terminan, tanto en la cabeza como en el pie, en rectángulos oblicuos — se utilizan únicamente en alguna pequeña línea o frase del texto-.

En los años 1870 asistimos a un aumento de la tipografía gótica en el cartel taurino, aunque siempre en muy contadas ocasiones y en pequeños textos. A partir de 1883 aparece la gótica de fractura. Este tipo de letra se ha convertido en la variedad más utilizada; es el resultado de la influencia renacentista en los caracteres góticos. Las letras ascendentes de caja baja tienen unas cabezas características, muy pronunciadas, en forma de horquilla; la «a» de la caja baja carece de lazo en la cabeza y la «g» tiene una cola en forma de curva abierta.

También los estilos antiguos, basados en el romano del siglo xvIII, siguen subsistiendo. A partir de 1858 el "ezelviriano» - cuya característica principal es el remate triangular- se pone de moda por el tipógrafo Théophile Beaudoire, deseoso de librarse del estilo Didot, reinante sin oponente en la tipografía francesa desde hacía tres cuartos de siglo. Nuevos modelos inspirados en las capitales romanas de inscripción hacen su aparición.

El "elzeviriano» (sinónimo hasta hace poco de romano en España) se convertirá en el carácter de base para todas las imprentas de Europa, fundamentalmente por lo que respecta a los caracteres de obra. No hay que olvidar que a partir del año 1857 hay un verdadero retorno a lo antiguo. A finales del siglo pasado, las "latinas» pretenden adaptar a su época el estilo de las inscripciones de la columna de Trajano. Las letras latinas con remates hendidos se utilizan pronto en los caracteres titulares (Fig. 6). El primer caso del nuevo «ojo fiaco» ${ }^{29}$ es el de las latinas que Laurent y

28 MClean. Op.cit., pág. 63.

29 Ojo flaco: se llama ojo de la letra al espacio blanco - no impreso- que queda en el interior. La perfección de un ojo bien diseñado se comprueba en la impresión de cuerpos pequeños, cuyo espacio blanco no debe quedar cubierto o "empastado» por la tinta que se acumula en los palos del tipo. La función del ojo es fundamental para proporcionar claridad de lectura al tipo diseñado. 


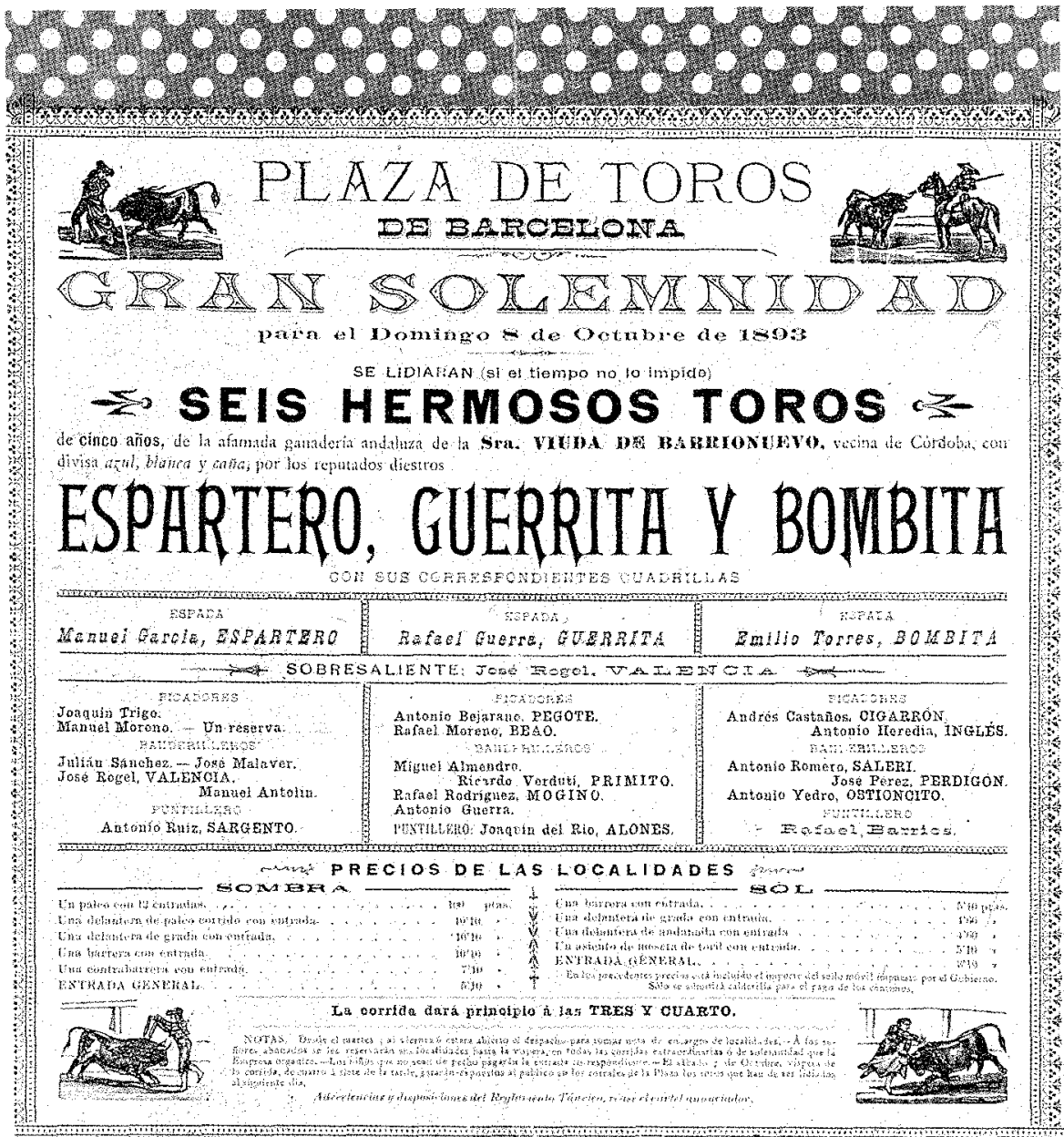

Whom

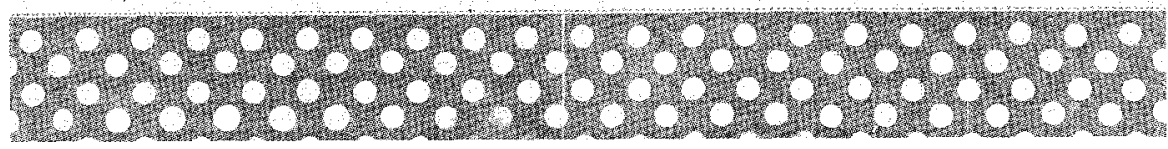

Fig. 6. Cartel fechado en 1893. M.N.A.

Deberny fundirán en varios gruesos a partir de 1854. Desde allí se extienden a Inglaterra, Caslon les dará el nombre de «rúnicas" que se conservan en varias versiones tanto americanas como inglesas. El mismo carácter, 
pero esta vez con remates de rúbrica o caligráficos, hizo su aparición entre 1864 y 1867 con el nombre de «monástico».

Otro carácter titular, un poco rudo pero eficaz, salió de las fundiciones inglesas Miller-Richard y Stephenson Blake hacia 1876, con los remates de las letras muy pronunciados en forma de triángulos. Se le llamó «old style antique» o «wide latin» (latino ancho).

Muchos son los carteles de toros de finales de siglo en los que podemos observar la influencia de estas tipografías. El fechado el 29 y 30 de Junio de 1889, además de un encabezamiento litográfico de derivación gótica, utiliza la familia de las lineales y el «latino ancho» en versales y negrita: «SEIS MAGNIFICOS TOROS». También introduce una escripta caligráfica en versal cuyo trazo se adorna con gran cantidad de apendices decorativos para el mote del matador: "TORERITO". Se siguen empleando gran cantidad de caracteres de fantasía: abiertos, calados, huecos, blancos, grises, perlados... y las escriptas caligráficas muy adornadas con remates de rúbrica para los motes de los matadores. Otros carteles emplean las "Latinas" en negrita del tipo de las fundidas por Laurent y Deberny en 1854.

El tipo de carácter llamado «Rúnico» fue una imitación inglesa, surgida entorno a 1874, de las letras latinas de Laurent y Deberny; muy parecido a éste, se empleó masivamente en el cartel taurino entorno a los años 1895, así como el llamado latino «ancho» o «antiguo», generalmente en versales de grandes cuerpos y en negrita, con terminales muy acentuadas en triángulos, aplicado sobre todo para los nombres de los matadores (Fig. 7).

\section{De 1880 a 1910 . El Modernismo}

La revolución industrial supuso la automatización y mecanización de la industria de impresión. Con la aparición de la litografía y casi inmediatamente de la cromolitografía - aplicada al cartel taurino en torno a los años 1880 - , se desarrollaron nuevas tendencias que afectaron, no solamente a la ilustración, sino también al diseño de letras.

La litografía anulaba la dependencia que con anterioridad había tenido el impreso con los artesanos profesionales, encargados de traducir - no siempre de manera satisfactoria - el dibujo original del artista. La invención de la litografía introdujo dos novedades fundamentales para el desarrollo del cartelismo: de una parte, el nuevo procedimiento permitía la impresión en color con mayor facilidad que la tipografía; de otra, la piedra 


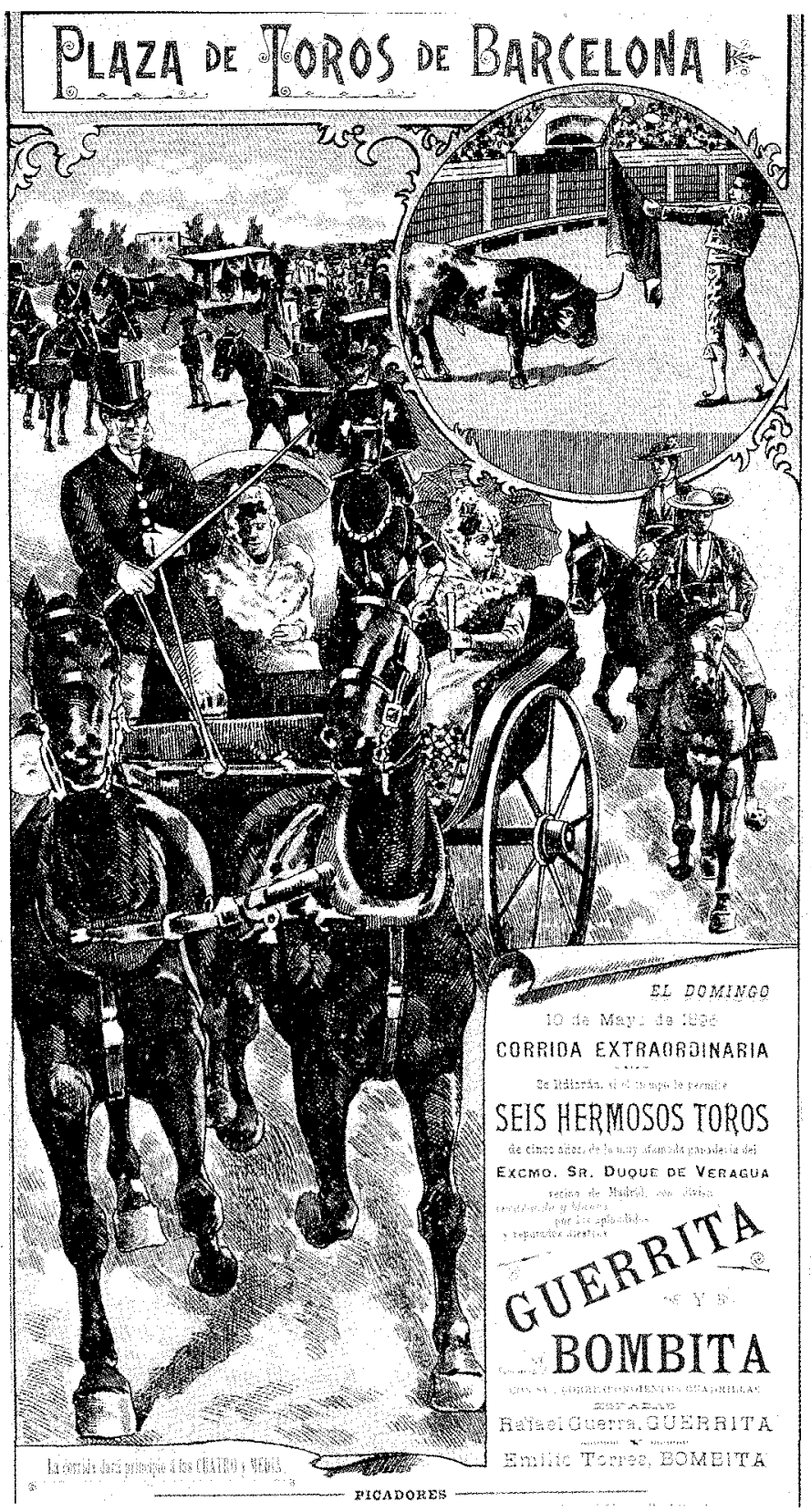

Fig. 7. Cartel fechado en 1896. M.N.A. 
caliza (y más tarde la plancha de zinc) que se empleaba como molde, otorgaba al artista la facultad de dibujar libremente sobre ella.

La posibilidad de dibujo directo y la importancia del color, dió como resultado la aparición de caprichosos tipos de letras personalizadas, trazadas con pincel, lápiz, cepillo o pluma ancha, cuya variedad era infinita por su condición caligráfica (al contrario que la tipografía).

La influencia de los artistas en los cambios tipográficos en el último cuarto del siglo XIX fue decisiva, afectando incluso a los grabadores de punzones, que se inspiraron en las letras litográficas de estos, caracterizadas por un estilo más espontáneo y autográfico.

La aplicación de este nuevo procedimiento de impresión tuvo también como resultado la configuración de dos tipos diferentes de carteles taurinos definidos por su formato: el cartel de mano, de pequeñas dimensiones, que se repartía al público y hacía las funciones de programa —con el "estadillo" en el reverso-y el cartel mural, de dos o tres metros, que ejercía como reclamo publicitario en vallas y paredes.

Los carteles de mano podían estar impresos únicamente en tipografía - con ilustraciones secundarias de viñetas y orlas - o mediante el procedimiento litográfico. En este último caso, el impreso se realizaba en dos fases que pasaban por dos establecimientos o imprentas diferentes: una imprenta litográfica especializada —como la casa Ortega de Valencia, la imprenta litografía Portabella en Zaragoza, Velasco o Palacios en Madrid, Heinrich \& Cía en Barcelona etc. - en la que se imprimía, por el procedimiento planográfico de la litografía, la ilustración y el texto del encabezamiento: «PLAZA DE TOROS» 0 «TOROS EN...» diseñado por el mismo artista que realizaba la ilustración; una imprenta o establecimiento local -exclusivamente tipográfico- donde, una vez conocida la fecha y la hora del festejo, así como el resto de los datos: ganadería, matadores, precios, actuaciones etc, se imprimía, en tipografía, el resto del texto y las ilustraciones y ornamentaciones secundarias, que podían ir sobreimpresas sobre la previa ilustración litográfica.

En el cartel de mano la tipografía (tipos en metal) no fue nunca realizada ex profeso para la función a la que estaba destinada. Se contentaron, para los caracteres grandes, con los cuerpos ${ }^{30}$ mayores utilizados en la composición de las portadas de los libros. Para la composición de carteles en material tipográfico se usaban caracteres de los cuerpos 16,$20 ; 24 ; 28$; 36 y 60 (más allá del 24 no puede hablarse ya de tipografía, distinguiendo

so Cuerpo: según la terminología tipográfica se corresponde con el tamaño del tipo o letra. 
entre los tipos para leer en bloque y las letras para contemplar en títulos, esloganes o rótulos).

Los carteles murales, debido a sus características intrínsecas y grandes dimensiones, obligaron a aumentar el formato de las letras de texto. Estas superaban, por su tamaño, el marco de la tipografía corriente, por lo que fue necesario que los fundidores proyectaran tipos móviles de madera y, más adelante, de un metal apropiado. A partir de los cuerpos 60072 , los caracteres se fabricaban en madera, generalmente de peral o de encina., utilizándose normalmente letras de 8 a 30 cíceros $^{31}$, así como blancos de todos los gruesos, cuyos cuerpos mayores eran fundidos en matrices de cobre o arena o tallados también en madera.

Los Estados Unidos se convirtieron en los grandes especialistas en la fabricación de estos caracteres de imprenta en madera. Desde 1870 abastecieron por completo el mercado americano y la mayor parte del europeo. Esta moda de los grandes carteles cromolitografiados de gran formato al gusto americano, fue introducida en España, más concretamente en Cataluña, en el año 1875, por Celestí Verdaguer ${ }^{32}$.

En los primeros carteles, la tipografía fue un medio de unión entre el contenido de la comunicación, por un lado, y el hombre que la recibía por el otro. Con la nueva técnica de la lito y la cromolitografía, comenzó una nueva etapa en su evolución, se empezó a considerar que el color, la forma, el formato, la disposición de las ilustraciones y de los materiales tipográficos, poseían una gran eficacia visual.

Sin embargo, el cartel taurino, por ser un género eminentemente popular, observó una escasa exigencia metodológica en el tratamiento gráfico. Hasta muy entrado el siglo xx, no se produjo la intervención del diseñador gráfico ${ }^{33}$, y ello siempre en circunstancias ocasionales. La mayor parte de estos impresos, se siguen diseñando, hasta hoy mismo, fuera del alcance de los círculos de influencias de los profesionales.

El cartel comercial y publicitario, continuó investigando por esta línea, organizando todos estos aspectos de eficacia visual, dando valor y entidad

\footnotetext{
31 Cícero: unidad de medida básica del material empleado en tipografía. Tiene doce puntos, que en el sistema Didot —usual en todos los paises salvo en Inglaterra y Estados Unidos- equivalen a $4,512 \mathrm{~mm}$.

32 Trenc I Ballester, E. Les arts grafiques de l'época modernista a Barcelona. Barcelona, Gremi d'industries grafiques, 1977, pág. 8.

33 En palabras de Satué (SATUE. Op.cit., pág. 133) este profesional sería el que «trata de lograr una síntesis orgánica entre las dos formas básicas de la comunicación impresa: el texto (tipografía) y la imagen (ilustración)".
} 
plástica al signo alfabético, remarcando el contenido de la comunicación. Pero el cartel taurino, tan hondamente arraigado en el subconsciente colectivo de sus consumidores, permaneció siempre reticente ante la renovación formal de sus imágenes de identidad originales: los cambios introducidos a través de los años, han sido escrupulosamente devotos a éstas.

La uniformidad en los mensajes y el divorcio entre tipografía e ilustración, serán sus principales características, desde los inicios hasta nuestros días. De otro lado, el hecho de que el contenido de la comunicación fuera mutable y cambiante - a cada festejo correspondía un texto diferente-, además de muy amplia — se ofrecían muchos datos-, le configurarán como un impreso publicitario alejado del cartel comercial. Al contrario que el cartel taurino, este último contenía pocos datos, por lo que le fue posible llegar a una síntesis orgánica entre las dos formas de comunicación visual: el texto y la imagen.

El cartel taurino, además, no solía diseñarse enteramente para una determinada corrida sino que, como hemos visto, se confeccionaba en dos fases. Este hecho generaba, lógicamente, la imposibilidad de realizar un diseño total en el que pudiera englobarse coherentemente la ilustración y la tipografía.

Por ello, lo habitual era que se realizara fuera de los cauces propios del diseño gráfico; siendo concebido, desde la aparición de la cromolitografía, como una ilustración con elementos tipográficos agregados. Tradicionalmente se producia en los talleres tipográficos, y era confeccionado e impreso por simples operarios, al margen de toda norma de diseño y legibilidad.

Por lo que respecto a este último concepto de legibilidad diremos que, si hay algo que caracterizó plenamente a la cartelería taurina, fue la variedad de tipos y familias de caracteres empleados en la misma. El impreso no tenía un estilo único, no habiendo cosa que afee más una composición gráfica que la mezcla de caracteres de estilo completamente dispares. No existían límites posibles, desde titulares de portadas de libros: floreadas, orladas, sombreadas, etc., hasta versales, versalitas, redondas, escriptas, manuales, cursivas, negritas, chupadas... Podemos encontrar en un único cartel hasta más de 15020 tipologías diferentes.

Es evidente que el impreso tiene un fin utilitario y funcional, puesto que debe servir para efectuar una comunicación, para transmitir un mensaje por medio de las letras. Quizá una manera peculiar de entender la «legibilidad" fue la causa de la utilización de diferentes estilos tipográficos de caracteres, diferenciando de esta manera las distintas partes integrantes de la información. Así cada dato informativo del cartel: plaza, hora, fecha, 
ganadería... se imprimió en un tipo de letra diferente que, de esta forma, quedaba enfatizada con respecto a la información anterior y posterior.

Es este un concepto muy decimonónico de «legibilidad», que se opone claramente a cualquier reglamentación racional, tal y como la enseñaban los antiguos maestros del Renacimiento y del Barroco y tal y como se aplicará en el siglo xx con la tipografía elemental y funcional.

En el último cuarto de siglo la influencia de los estetas y artistas se hizo del todo patente. El estilo espontáneo y autográfico de los virtuosos de la estampa -en España todos los hijos del Modernismo- fue un modelo continuo donde bebían los grabadores de punzones. Estos artistas, transformaron los usos de los titulares pero se desinteresaron, en general, por los caracteres de texto. El procedimiento técnico tipográfico trató de imitar, no sin dificultades, la imagen ideal de los caracteres titulares realizados a pincel o a pluma: es lo que Thibaudeau bautizó como «romano a pincel» o «escritura tipografiada». Este tipo de tipografía que imita la pluma y el pincel fue muy frecuente en el cartel taurino: las tipografías «Manuales», basadas en la familia "Lineal», comenzaron a florecer entorno al 1895. La imitación de la letra a pincel se hizo más fuerte a finales de siglo y trajo como resultado la aparición de caracteres inspirados en la caligrafía china.

En 1884 surgió un caracter mural (Manual) denominado tipo "Caslon». Muy similar a éste son los encabezamientos de los carteles fechados en 1896 (Fig. 7). Otro caracter de fantasía, salido esta vez de las fundiciones francesas, fue la letra «sudanesa», con las astas ligeramente curvas y terminales en forma de flecha que se utiliza muchísimo en el cartel taurino, tanto a finales del siglo pasado como a principios de éste (Figs. 6 y 7). También a finales de siglo aparecen en la cartelería taurina caracteres de fantasía muy decorados, con remates y apex hendidos o en forma de volutas, parecidos al tipo francés "Ombre perlee», que surgió de la fundición Chaix en 1885, y similares a las llamadas "Toscanas», tan empleadas en los «posters» publicitarios americanos. La familia de las «Escriptas» se empleó continuamente en caligrafías parecidas a la letra «inglesa» 0 «bastarda».

Desde 1880 hasta 1910 podemos encontrar una cierta continuidad estilística que nace en el historicismo y el último Romanticismo, en la Restauración y que recibirá influencias de Inglaterra (esteticismo, prerrafaelismo), de Francia, del naturalismo, del orientalismo, etc. El Modernismo ${ }^{34}$, coincide con el periodo de esplendor de las artes gráficas

${ }^{34}$ Para el diseño Art Noveau vid. Fanellı, G. El diseño Art Nouveau. Barcelona, Gustavo Gili, 1982. 
en general. Su interés se expande hacia todo tipo de impresos: carteles, etiquetas, ex libris, etc...impresos que van desde el libro de bibliófilo hasta la publicidad de productos de consumo para las mayorías. Como bien dice Romá Arranz ${ }^{35}$ : «En las artes gráficas conviven los dos sistemas de producción, el artesanal, que defendió en Inglaterra Morris y que tiene en Cataluña su paralelismo en la obra de Eudald Canibell, de Maria Aguiló o la imprenta Oliva de Barcelona, y el industrial, en grandes imprentas como la Montaner i Simón, Henrich - sucesora de Narcís Ramírez-, Salvat y Pujades o la de Lluís Tasso".

El siglo $x \mid x$ trajo consigo notables cambios en la imprenta debido a la mecanización, sin embargo, también supuso una disminución de la calidad gráfica que en muchos casos llegó a ser muy deficiente. Ante esta situación de caos morfológico, caracterizado por tipografías frívolas y convencionales, desconectadas del contenido al que servían, surgió en Europa un movimiento de restauración del libro artesano que fija su atención en lo medieval, dentro de una oleada neogótica que afectó a todas las manifestaciones artísticas y culturales ${ }^{36}$. Movido por este afán William Morris ${ }^{37}$, en la última década del siglo, hará revivir el estilo y la forma de la tipografía clásica, basándose en la letra gótica.

Antes que él, en Cataluña, María Aguiló y Fuster (1825-1897) realizó, en 1833, un Gótico Tortis ${ }^{38}$. Eudal Canibell i Masbernat (1858-1928), uno de los personajes más relevantes de las artes gráficas catalanas de fin de siglo, diseñó en 1903 por encargo de la Societat Catalana de Bibliófils, un tipo de gótico conocido como Gótico Incunable Canibell ${ }^{39}$. Entrado el siglo XX, contamos con realizaciones plenamente neogóticas de gran prestigio casi hasta 1920 (edición del «Quijote» que hizo la imprenta de Octavi Vixader en San Feliú de Guixols en 1916, usando el gótico de Canibell ${ }^{40}$ ).

\footnotetext{
35 Arranz, R. «De la imprenta en la época modernista», en (Exposición) El Modernismo. Barcelona, 1990. págs. 277-286.

36 Dentro de esta corriente habría que situar la obra de William Morris y también la de Walter Crane, colaborador asiduo de éste último y notabilísimo ilustrador que jugo un papel pionero en el desarrollo del estilo Modernista. Entre sus obras destacan: "On the Decorative lllustration of Books Old and New» (1896); "Claims of Decorative Art»(1892); «The Bases of Design» (1898); «Lire and Form» (1900).

37 Watkinson, R. William Morris \& Kelnscott. London, The Dessing Council, 1981. Morris, W. The ideal Books: essays and Lectures on the Arts of the Boouk. Los Angeles, University California Press, 1982.

38 VELEZ, P. El llibre com a objecte d'art a la Catalunya vuitcentista (1850-1910).Barcelona, Biblioteca de Catalunya, 1989. OLıva, V. «El gótico incunable Canibell», Revista Gráfica. Barcelona, 1904. págs.18-20.

39 Trenc, E. Op.cit., págs. 21-26.

40 VELEZ, P. «De la caligrafía gótica a la imprenta neogótica», Fragmentos. Núms. 17,18 y 19, Madrid, 1991, págs. 145-150.
} 
Es cierto que esta utilización de la tipografía gótica se reservó únicamente para libros muy valiosos y de cuidada edición. Sin embargo, el interés general por la recopilación del gótico a finales del pasado siglo, incrementó esa tipografía, aunque de manera esporádica, en otros impresos más populares como el cartel taurino. La Casa Romá i Cía de Barcelona editó un «Album Caligrático Universal», en el que se recogían quince abecedarios góticos completos en catalán y castellano, que influyeron fundamentalmente sobre el libro impreso de bibliófilo o de lujo.

El empleo de la litografía en la cartelería taurina, trajo también como consecuencia la aparición de un sinnúmero de letras litográficas, manuales y personalizadas que, diseñadas por el autor de la ilustración, se sitúan en el encabezamiento de la misma: titulares de influencia gótica letras caladas o abiertas de derivación gótica. Todas ellas caracterizadas por la falta de "legibilidad" y la excesiva ornamentación - flores, instrumentos musicales, trastos de toreo, etc.- por el énfasis puesto en la decoración que rodea los caracteres, más que por el propio diseño tipográfico. Son letras dibujadas, irregulares, muy fracturadas, con abundancia de roleos, imitando letras recortadas, en relieve o sombreadas (Fig. 8).

En el cartel taurino de este momento encontramos un número infinito de letras y tipografías personalizadas de la familia de las manuales, diseñadas por medio del procedimiento litográfico. Muchas de ellas se inspiran en la caligrafía gótica a base de remates en oblicuo y formas muy fracturadas. Esta tipología predomina en todos los encabezamientos litográficos del último cuarto del siglo xIx. El interés por el Gótico es una de las consecuencias del movimiento Romántico, impregnado de un gusto medievalista muy de moda por aquel entonces, como lo demuestra el cartel fechado el 7 y 8 de Septiembre de 1895 (Fig. 9) en el que el artista alicantino Bañuls, diseña una cabecera con motivos arquitectónicos de caracter románico y tipografía de influencia gótica, dentro de una órbita de evidente eclepticismo y falso historicismo.

Además del gótico y la caligrafía inglesa, la tipografía modernista se caracterizó por la utilización de caracteres que, basándose en la familia de las lineales (grotescas, antiguas, góticas o palo seco), se recargaban al máximo en curvas y contracurvas, disimetrías, alargamientos etc. Ya lo habían hecho los modernistas franceses como Auriol y Grasset, con sus letras que parecían realizadas a pincel, con palos largos y curvados, más anchas en el extremo y con desunión de las astas. Es un tipo de letra muy decorativa, que rehuye la regularidad y la monotonía de la línea recta, de los ángulos duros, y en definitiva, de toda la tradición anterior. 


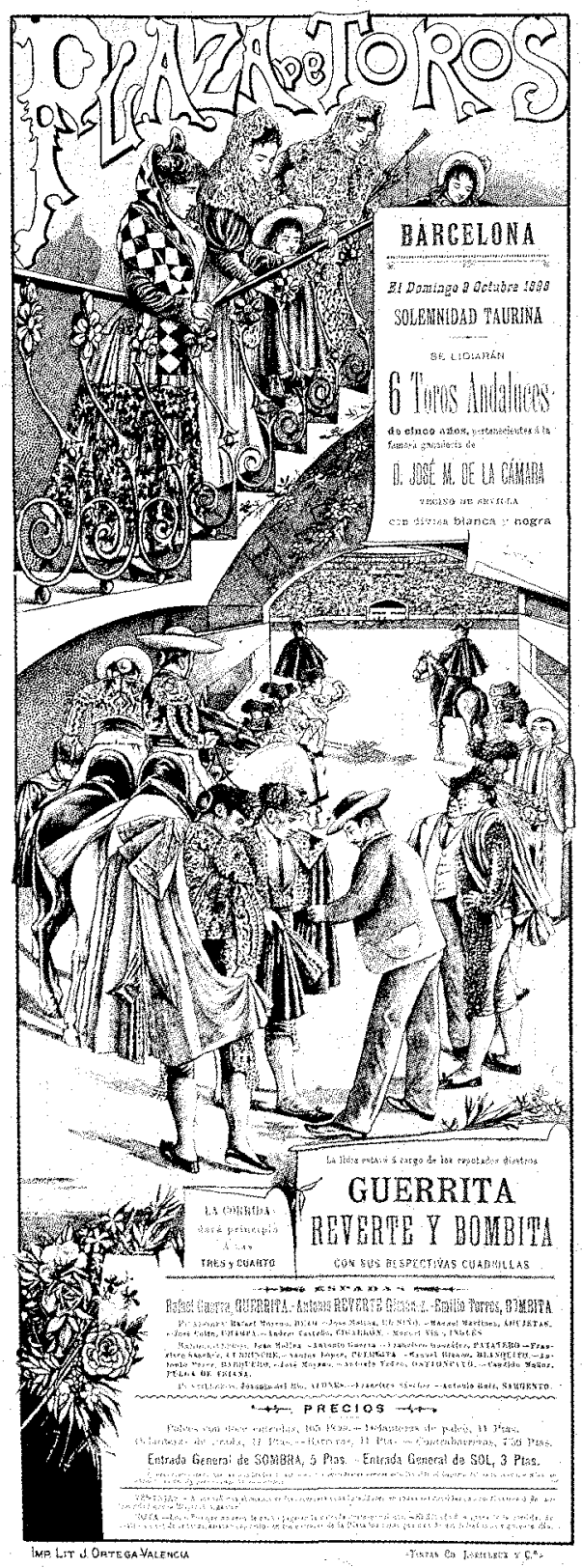

Fig. 8. Cartel fechado en 1898. M.N.A. 


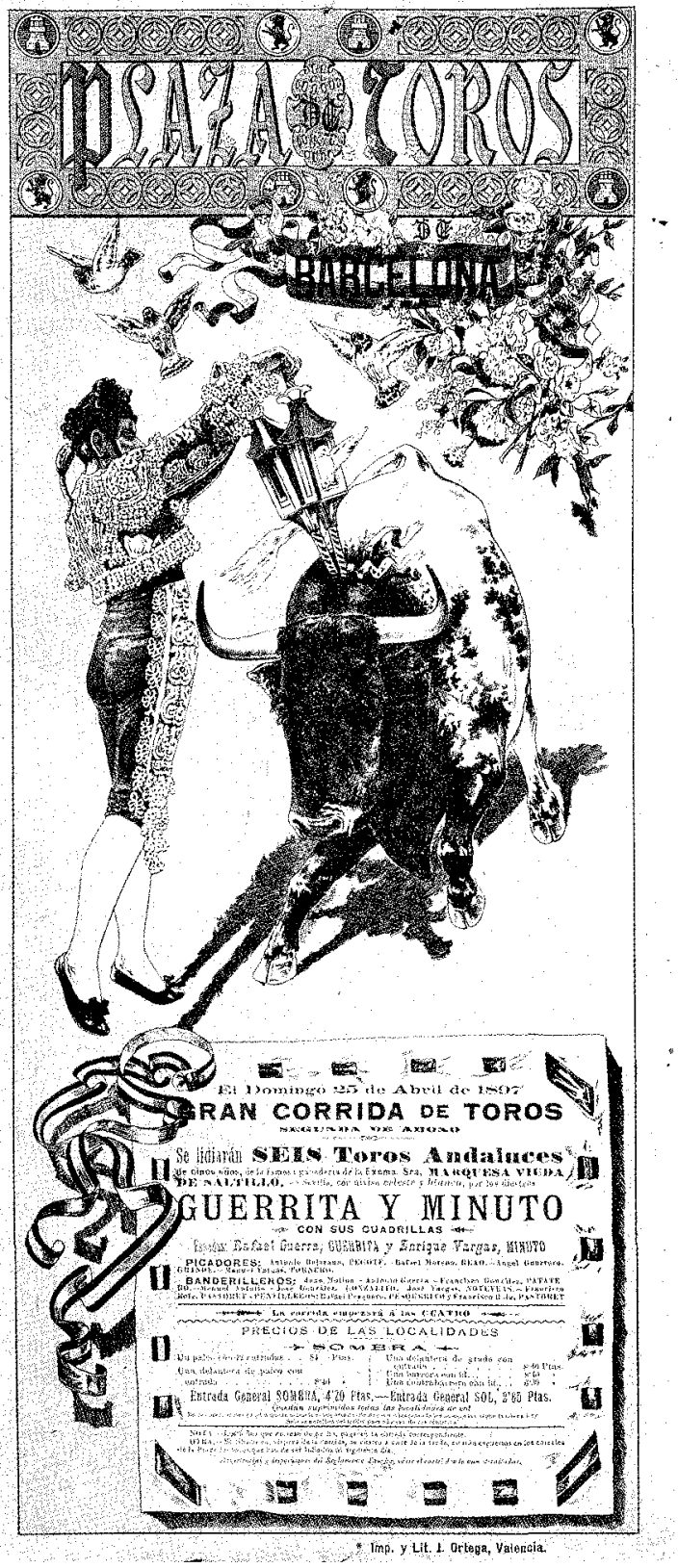

Fig. 9. Cartel diseñado por Vicente Bañuls en 1895. M.N.A. 
La adopción de esta tipografía comienza en el cartel de toros en torno a los años 1890, con la utilización de mayúsculas con efecto de relieve y sombreadas, letras entrelazadas, englobadas unas en otras, formando un conjunto decorativo y compacto.

Desde principios del siglo XIX, las fundiciones inglesas ejercieron una soberanía en toda Europa y en América, pero a partir de los años 1870 más o menos, fueron destronadas por las crisis económica y la prosperidad de las fundiciones alemanas. Los tipos ingleses y americanos tuvieron en España únicamente una influencia indirecta, pero casi nunca fueron exportados a nuestro país, puesto que sus medidas no coincidian con las europeas.

Por el contrario, sí tuvieron una influencia importantísima las fundiciones alemanas. Una de las fundiciones catalanas de más prestigio (Neufville) era una sucursal directa de la Bauer alemana. Esta fundición colaboró con el diseñador de tipos más plenamente modernista: Friedrich Wilhelm Kleukens, que elaboró una gran cantidad de normas tipográficas y alfabetos basados en el romano y caracterizados por el aspecto geométrico y la línea aguda de raíces claramente vienesas. La Neufville los incluyó en sus catálogos, siendo este tipo de origen romano el que más se empleó durante el novecentismo.

En Barcelona, las grandes fundiciones alemanas estaban representadas también por Pundsack, el gran importador de material de imprenta. Esta influencia dió a la producción de tipos española un carácter decididamente extranjero, únicamente obviado por la creación de los tipos de letra verdaderamente autóctonos.

Muchos de los caracteres Art Nouveau franceses como el "Grasset" -que lleva el nombre de su creador- entraron en España a través de las fundiciones alemanas como la Genzsch \& Heyse de Hamburgo ${ }^{41}$. Este carácter consistía en una modificación de la «Antigua» clásica, que la hizo asimétrica y perfilada. Aunque Trenc ${ }^{42}$ opina que fue poco empleada por los impresores catalanes -lo mismo que el carácter «Auriol»- es posible encontrar tipologías muy parecidas en algunos carteles taurinos de la primera mitad del siglo $\mathrm{xx}$.

Como bien dice Eliseo Trenc ${ }^{43}$, fue el tipo «grotesca» (lineal) el punto de partida para la creación de caracteres Art Nouveau. La fundición Neufville de Barcelona disponía de varios caracteres de grotesca:

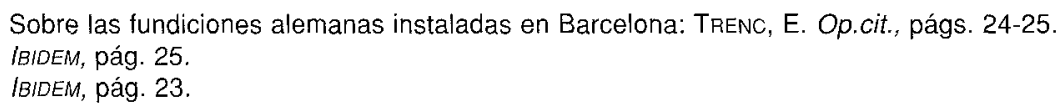


«La Grotesca fantasía», muy utilizado en los carteles de toros hasta los años 1930, se caracterizó por el grueso del grafismo que aumenta progresivamente hacia los extremos, las líneas verticales curvas y la discontinuidad de las líneas en las mayúsculas «R», «M», «D». (Fig. 10).

«La Grotesca artística» tiene todas las mayúsculas y las líneas verticales curvas, la «R» y la «P» dibujan un triángulo asimétrico, las letras son de dimensiones irregulares, siendo la «O» mayúscula más pequeña. Ese tipo de letra y otras derivadas de ellas se utilizó mucho en las letras manuales litografiadas en diversos carteles (Fig. 11).

«La Grotesca Secesión»: muy empleada en impresos publicitarios, se caracterizaba por las astas deshiladas de las letras «a», «n»y «m» y por la forma asimétrica de la «B», «S»y $y$ «D mayúsculas (Fig. 12).

«Cleopatra»: caracter muy elegante, típicamente Art Nouveau, en el que las intersecciones entre dos líneas en una misma letra no son nunca perpendiculares, sino tangentes, con claro dominio de la línea curva, la «V» y la «y» muy asimétricas y la utilización de letras entrelazadas o ligadas (Fig. 13).

Era muy normal encontrarnos el mismo tipo de letra en diferentes fundiciones, puesto que muchos dibujantes calígrafos trabajaban libremente y vendían sus productos a las mismas; algunos de ellos, en cambio, comenzaban a estar ligados a fundiciones concretas. La fundición Antonio López tenía entre sus caracteres y sus catálogos un tipo llamado «grotesca modernista» que es la misma que la "grotesca secesión» de Neufville.

Otro caracter de los catálogos de la imprenta Antonio López es el llamado «Fantasía Hispanoamericana", letra rebuscada y original, mezcla entre la gótica y la grotesca con bases curvas y terminaciones en forma de bola.

La fundición Rey, Bosch \& Cía de Madrid, presentaba caracteres Art Nouveau inspirados en una grotesca; el caracter de la «Serie V" se asemejaba mucho a las letras de los carteles.

En la Exposición Nacional de Minería de 1873 figuran las industrias más prestigiosas madrileñas, como la tundición tipográfica de Richard Gans, que estaba ubicada en la calle Villanueva 22, y después se trasladaría a la calle Princesa 63. Esta diseñó un gran número de tipos modernos de fantasía de origen alemán ${ }^{44}$ : el «Velazquez», que es igual al llamado «Fantasía Hispanoamericana» de la fundición Sucesores de Antonio López; el «Helios», muy irregular, en el que el arabesco y el grafismo es interrumpido por las intersecciones de las líneas; el «Regina», caracter típicamente Modern Style por lo irregular y asimétrico de los modelos, construidos en base a una forma triangular con intersección tangencial de las líneas.

44 IBIDEM, págs. 23-24. 


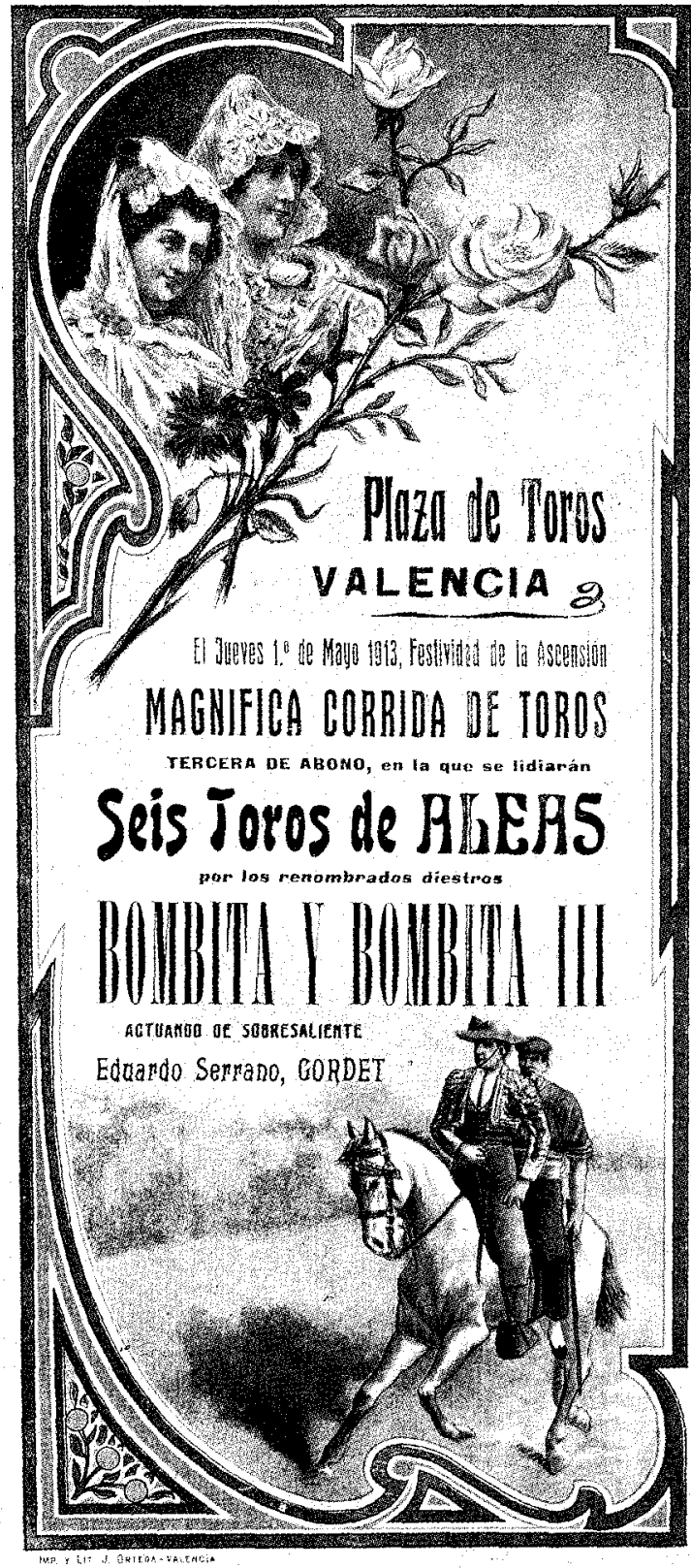

Fig. 10. Cartel con caracteres "grotesca fantasia», 1913. M.N.A. 


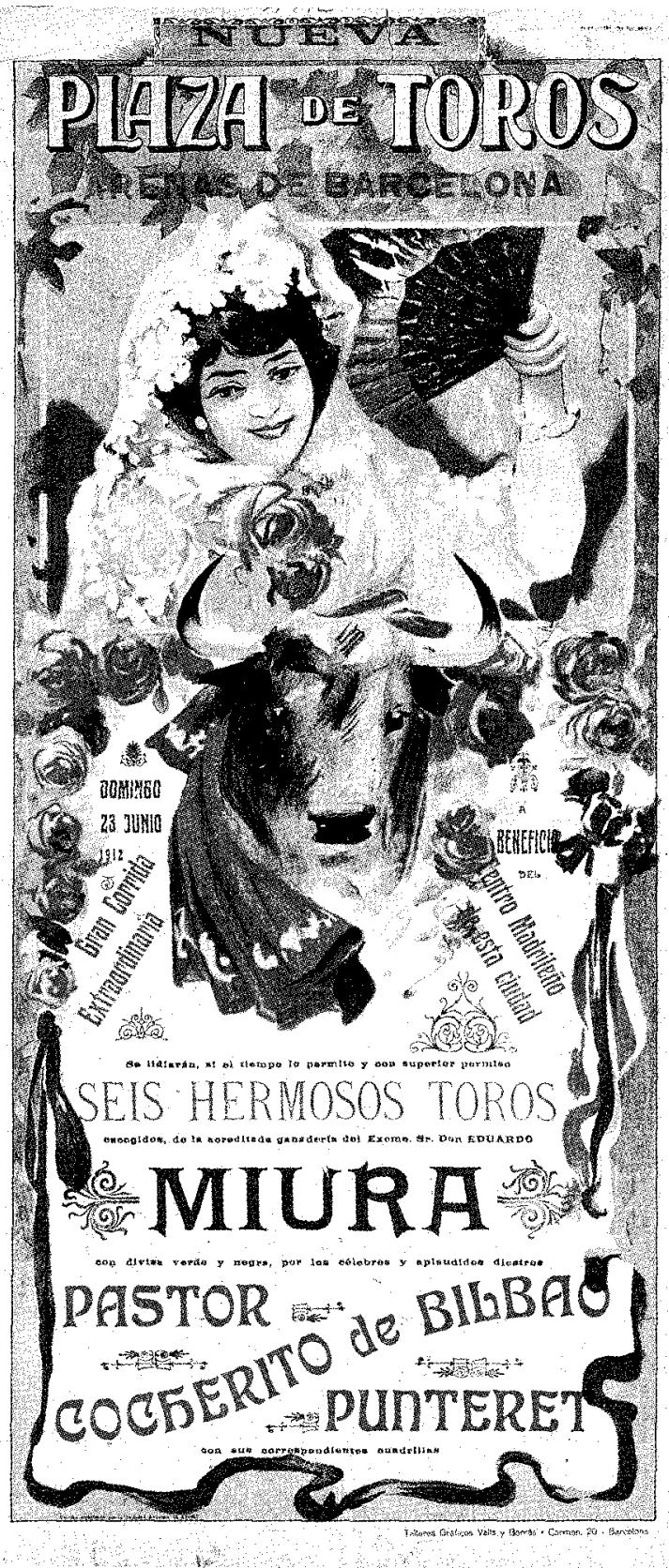

Fig. 11. Cartel diseñado con caracteres «grotesca artística», 1912. M.N.A. 


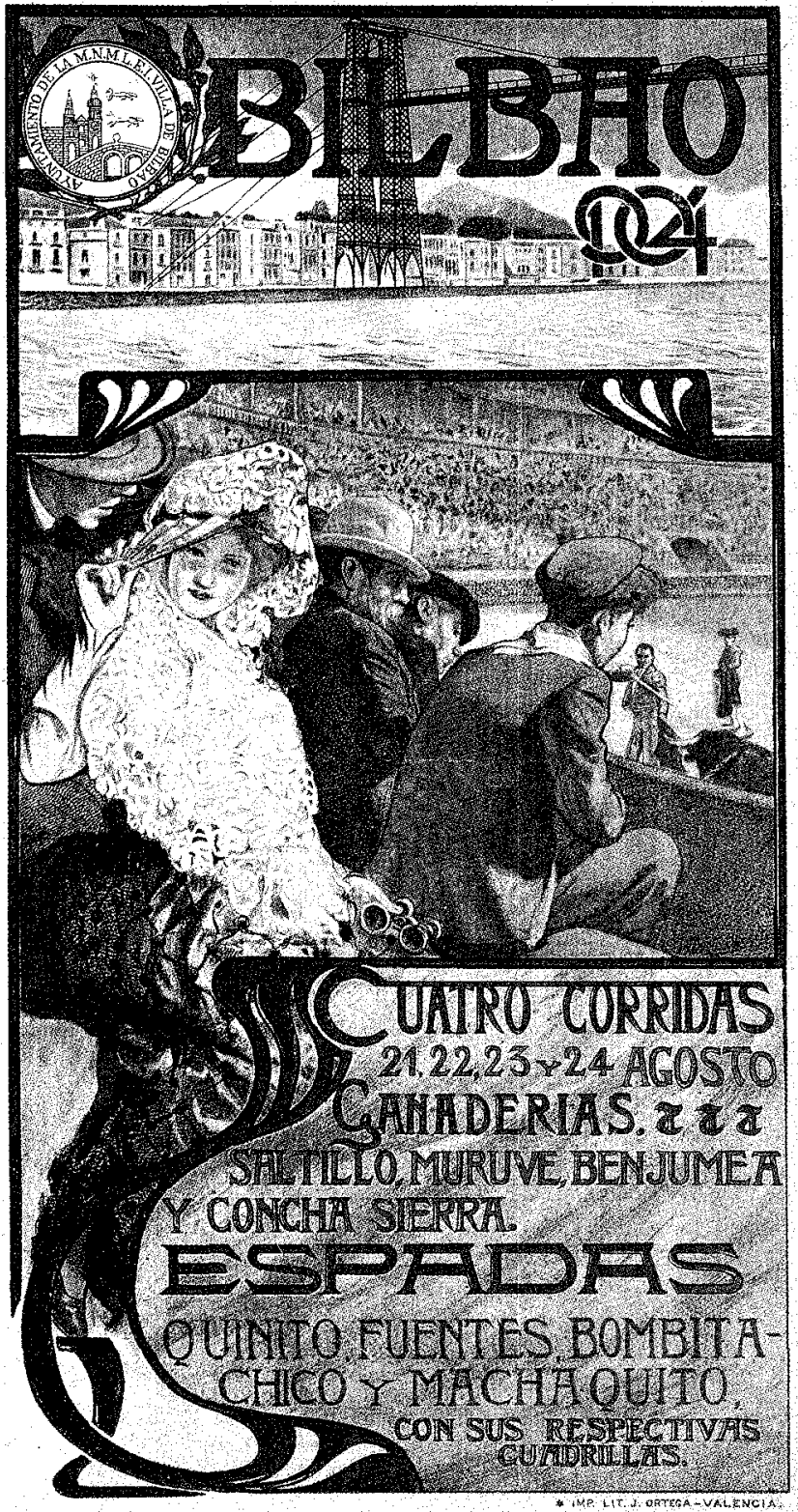

Fig. 12. Cartel diseñado manualmente con caracteres «grotesca secesión», 1904. M.N.A. 


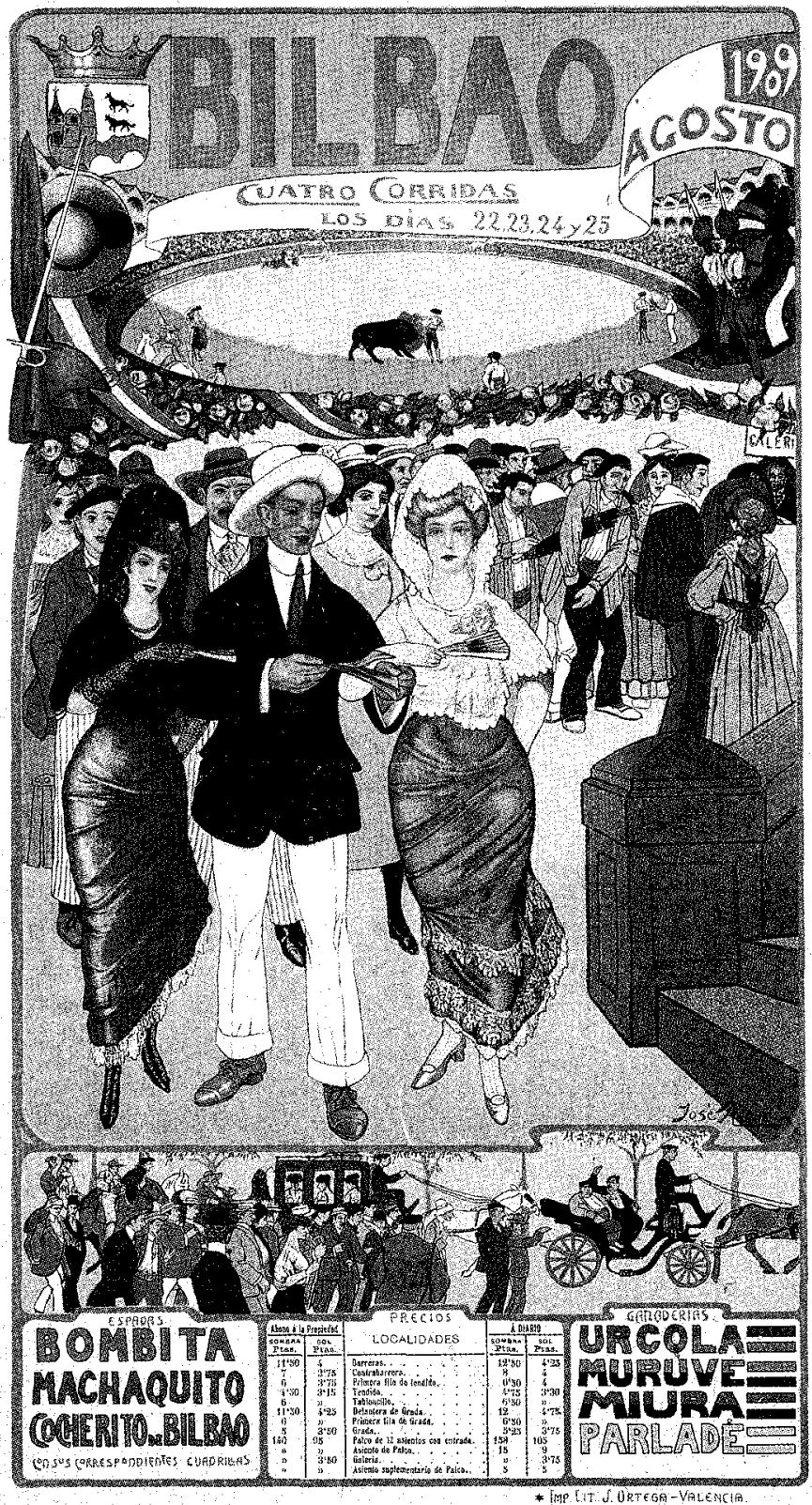

Fig. 13. Cartel diseñado manualmente con caracteres «Cleopatra», 1909. M.N.A. 
Disponía además de dos góticos modernizados: el «uncial» ${ }^{45}$ que inscribía idealmente cada letra en un cuadrado y el «Gótico Globus» que lo hacía en un rectángulo, adoptando la forma oval, y tres tipos de caracteres inspirados en la caligrafía chinesca ${ }^{46}$ : «la madrileña» y «la nacional» eran más occidentalizantes y regulares, "la japonesa" era curva e irregular. La "serie l» de la fundición Antonio López se nutría también de la caligrafía oriental.

La influencia del mundo oriental, en concreto la china y japonesa, fue decisiva sobre determinados aspectos estéticos. La muestra japonesa en la Exposición de 1862 en Inglaterra o la de la Exposición Universal de París en 1867, fueron algunos ejemplos aislados de estas relaciones. Como de todos es sabido, el Modernismo hizo suya la estética japonesa, que ejerció notable influencia sobre las artes en general. La caligrafía chinesca y japonesa, caracterizada por un tipo de letra que parece realizada a pincel, con curvas y trazos discontínuos, se fundió también en tipos metálicos. La forma de las letras, más libre y asimétrica y el grafismo irregular, encajaban perfectamente con la estética del momento, introduciéndose en el cartel de toros entorno a principios del siglo xx y perdurando hasta el año 1912 aproximadamente.

Para finalizar y resumiendo, podemos decir que la tipografía del siglo XIX en el cartel taurino se caracterizó por la utilización de caracteres de fantasía con formas ostentosas de gran pretensión y por el empleo, dentro de un mismo impreso, de diferentes familias y estilos tipográficos. Ya se intuía, no obstante, la clave publicitaria de ofrecer el nombre del protagonista (el matador) en caracteres gruesos, destacados y más negros. Las líneas podían estar dispuestas en formas caprichosas, curvas, onduladas, diagonales y en zig-zag combinadas con las horizontales de lectura más normal. Los gustos por las letras eran muy variados, aunque predominaba las llamadas de «media caña», en las que, junto al trazo grueso de la letra, se añadía otro fino, paralelo al anterior. Gustaban de la mezcla de caracteres finos con tipos gruesos, se combinaban ligeras letras inglesas con gruesas góticas y romanas, siempre queriendo dar idea de prestigio, se realzaba su contorno con un batiente de línea o bien adornando las mayúsculas iniciales con rizos y filigranas.

Cuando se trata de las letras litográficas de los encabezamientos, los diseñadores, en vez de simpiificar las formas, las adornan y recubren de motivos hasta deformarlas o disimularlas. A partir del último

45 Uncial = mayúscula.

$4 \hat{6}$ Trenc, E. Op.cit, pág. 23. 
cuarto del siglo, la tipografía comienza a imitar la letra realizada manualmente a pincel o pluma, cambiando las pendientes de las cursivas, invirtiendo la distribución de los gruesos; se decora todo y también se cambia todo, principalmente, el relieve y el efecto; hay un marcado gusto por el uso de las letras de batiente sombreado, con un aire de perspectiva y relieve cincelado, a base de ilusión óptica. Se utiliza toda clase de estilos: clásicos, ezelvirianos, didot, antiguas, egipcias, latinas, sombreadas, cuadradas, abiertas, redondas, estrechas, orladas, con remates hendidos, con curvas, con bolas, cortados... Todo ello en cuanto a los caracteres titulares. En cuanto a los caracteres de obra, aunque se marca una proliferación, hay menos confusión. Los caracteres de texto se emplean en el cartel taurino fundamentalmente para la información menos importante: cuadrillas, advertencias, precios. Las variaciones se centran en la forma - negrita, versal, cursivo, redondomás que en el estilo, que sigue teniendo como caracter de base el ezelviriano o romano clásico.

El papel de la industria de fundición en nuestro país no fue en absoluto vanguardista, limitándose a recoger tipografías acreditadas ya en Europa, con la excepción, como se ha dicho, de algunos ensayos de tímidos y convencionales alfabetos "autóctonos» que afectaron más a la edición de libros de calidad que a la cartelería. Habrá que esperar a los años 1930, aproximadamente, para que auténticos profesionales de la gráfica se atrevan a diseñar conjuntamente la ilustración y el texto. Aun así, y por lo que se refiere al cartel taurino, esto ocurrirá sólo en muy contadas ocasiones. 
